\title{
Sex steroids in the tumor microenvironment and prostate cancer progression
}

\author{
Clovis Boibessot and Paul Toren \\ Department of Surgery, Laval University, Quebec City, Quebec, Canada \\ Correspondence should be addressed to P Toren: paul.toren@crchudequebec.ulaval.ca
}

\begin{abstract}
Prostate cancer is uniquely dependent on androgens. Despite years of research on the relationship between androgens and prostate cancer, many questions remain as to the biological effects of androgens and other sex steroids during prostate cancer progression. This article reviews the clinical and basic research on the influence of sex steroids such as androgens, estrogens and progesterone within the prostate tumor microenvironment on the progression of prostate cancer. We review clinical studies to date evaluating serum sex steroids as prognostic biomarkers and discuss their respective biological effects within the prostate tumor microenvironment. We also review the link between genomic alterations and sex steroid levels within prostate tumors. Finally, we highlight the links between sex steroid levels and the function of the immune system within the tumor microenvironment. As the context of treatment of lethal prostate cancer evolves over time, an understanding of this underlying biology remains central to developing optimal treatment approaches.
\end{abstract}

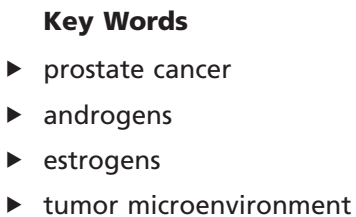

Endocrine-Related Cancer (2018) 25, R179-R196

\section{Introduction}

The significance of androgens and other sex steroids during androgen deprivation therapy (ADT) continues as an area of further exploration over 70 years since Huggins and Hodges first described the androgen dependency of prostate cancer (PCa) (Huggins \& Hodges 1941). Androgens, as well as estrogens and progesterone, appear to play a significant role in not only carcinogenesis, but also on the progression of PCa. Castration remains the primary treatment for advanced prostate cancer, with androgen receptor (AR) pathway inhibitors used for castration-resistant prostate cancer (CRPC). Through the development and subsequent treatments for $\mathrm{PCa}$, endocrine and paracrine systems regulate a prostate tumor microenvironment (TME), which is constantly exposed to circulating sex steroids. As our understanding of how circulating and locally produced sex steroids impact cell autonomous and non-cell autonomous mechanisms of tumor resistance within the TME advances, we may better harness the ability of local and circulating sex steroids to act as biomarkers.

Historic interest in the role of sex steroids on PCa progression dates mostly to the role of adrenal androgens and intratumoral androgen synthesis (Bélanger et al. 1984). Combined blockade of adrenal androgens with AR antagonism underwent extensive clinical evaluation, but the net clinical benefit was ultimately marginable (Lukka et al. 2006). Nonetheless, the success of the steroidogenesis inhibitor abiraterone as treatment for CRPC highlights the importance of understanding this biology (de Bono et al. 2011, Ryan et al. 2013a).

More recently, several important discoveries have re-ignited interest as to the importance of sex steroids 
on PCa progression. Nadir testosterone levels following ADT initiation have now been established as a reliable prognostic marker for the long-term development of resistance and PCa mortality (Klotz et al. 2015). Subsequent widespread interest now exists to target lower castrate levels of testosterone, despite a clear biological rationale for these findings and a lack of clinical evidence that this will improve outcomes. Secondly, the identification of several genotypes and mutations, which influence sex steroid metabolism within the prostate microenvironment has also further spurred interest in the hormonal milieu as a key factor in both castration-sensitive and CRPC. Finally, the link between sex steroid levels and autoimmunity presents an interesting outlook on potential efficacy of immunotherapies in PCa (Lin et al. 2010).

In this review, we discuss the clinical and biological effects of sex steroids within the prostate TME on PCa progression and resistance. We review the available clinical data on changes in sex steroids in PCa patients, which occur following ADT and progression of disease. Secondly, we review the available data on the relationship between circulating sex steroids and their levels in the prostate TME. Next, we review the clinical impact of measurable genetic variations in genes related to sex steroids and role of serum sex steroids as biomarkers. Finally, we discuss the effects of different sex steroids on cells within the prostate TME. Specifically, we will discuss the potential links between intracrinology and immunology, emphasizing the potential interactions with the innate immune cells of the TME.

\section{Sex steroids and steroidogenesis}

Sex steroids are all biochemically based on a 17-carbon 4-ring backbone. Androgens and their metabolites have 19 carbon molecules, estrogens have 18 carbons, progestogens, glucocorticoids and mineralocorticoids have 21 carbons. Clinically, sex steroids are defined by their effects on sexual differentiation and maturation, with effects recognized to be dependent on concentration and exposure. In the cell, sex steroids may bind to cognate receptors, translocate to the nucleus and affect transcriptional changes or alternatively induce changes through non-receptor mechanisms.

Biosynthesis of sex steroids is performed by multiple enzymes through multiple intermediates. A summary and simplification of the major intermediates and key enzymes is presented in Fig. 1. Unique gene transcripts encode each enzyme, with tissue-specific expression throughout the body. In men, androgens are primarily synthesized by the Leydig cells of the testis and in the glomerulosa reticulata of the adrenal gland. Steroidogenesis is highly complex, and there remains much detail, which is incompletely understood. A summary of the function of steroidogenesis enzymes is reviewed in detail elsewhere (Zhang et al. 2016).

The hormonal milieu within prostate tumors is influenced by both intratumoral production of sex steroids as well as the circulating endocrine system. Levels of sex steroids in the circulation are carefully regulated by the hypothalamic pituitary axis as well as via the adrenal cortex. Obesity is another key regulator of systemic sex steroid levels, with peripheral conversion of testosterone to estrogens occurring via aromatase in adipocyte tissue. The association of periprostatic adipose tissue with more aggressive PCa may also represent a more local source of estrogenic conversion (Toren \& Venkateswaran 2014).

The measurement of sex steroids is a common confounder in many studies and creates difficulties in interpreting the literature; guidelines exist for standardized methodology endorsed by the Endocrine Society. Determination of serum sex steroids is most accurate using LC-MS/MS methods, while immunohistochemical or radioimmunoassay methods are less reliable. Overall, the complexity of the biology as well as the many confounders including measurement accuracy present important potential confounders to consider when evaluating clinical studies measuring sex steroids in PCa patients.

\section{Changes in sex steroids during prostate cancer progression}

\section{Physiologic changes in aging men}

Prostate cancer occurs predominantly in older men. Several changes in sex steroids have been described in the serum and prostate tissue of older men. In the serum, levels of testosterone and its metabolite dihydrotestosterone (DHT) tend to decrease gradually with age (Araujo et al. 2004, Yeap et al. 2014). Estradiol levels also tend to slowly decrease with time, but not always to the same extent given the moderating effect of increased peripheral aromatization caused by obesity (Vermeulen et al. 2002).

Benign prostatic hyperplasia $(\mathrm{BPH})$ also variably occurs in men as they age. Sex steroid levels in serum and prostate tissue were recently accurately characterized in men without PCa (Neuzillet et al. 2017). Comparing the differences in serum and tissue sex steroids between 


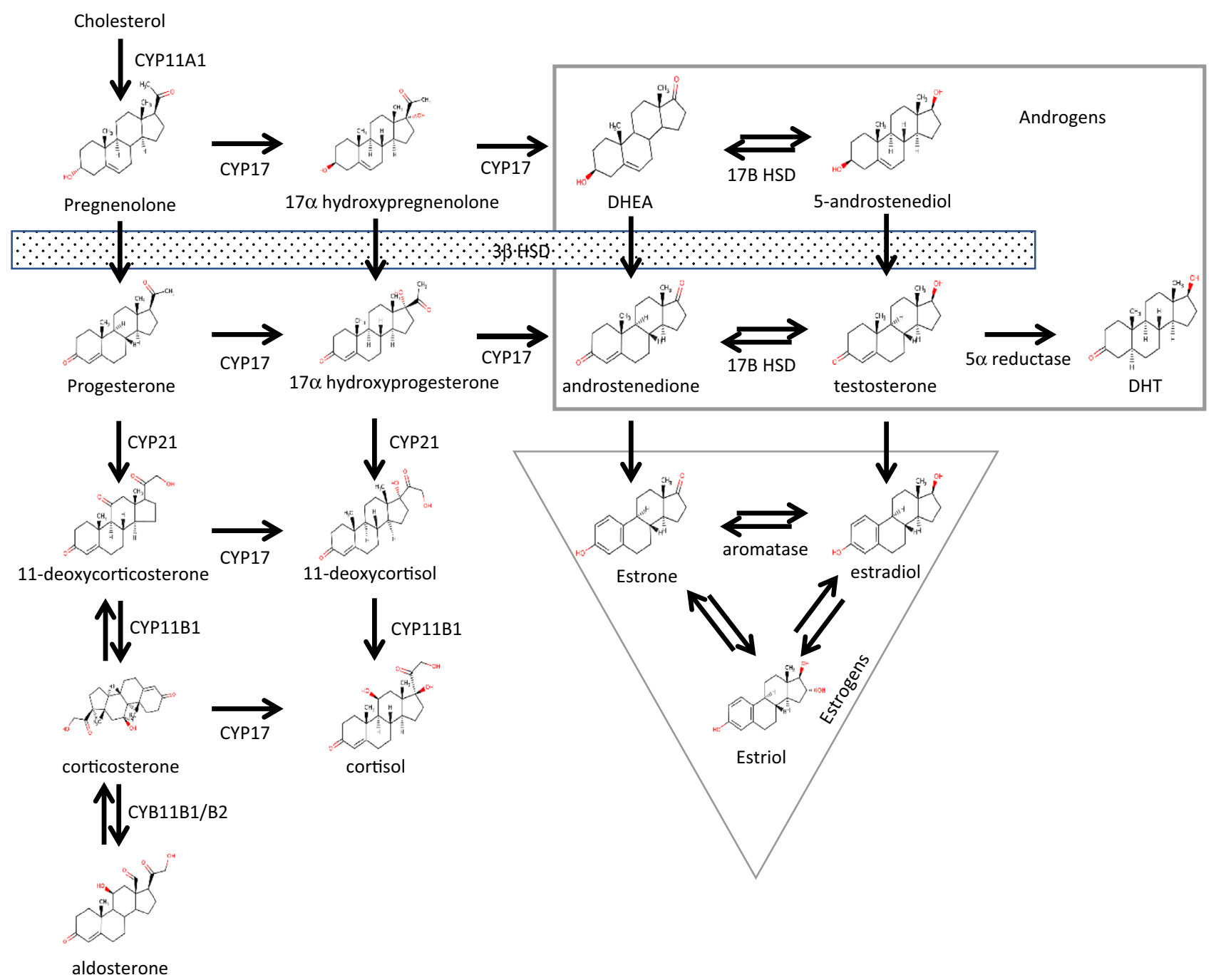

Figure 1

Schematic of the steroid biosynthesis pathway. Data from Locke et al. (2009). A full color version of this figure is available at https://doi.org/10.1530/ ERC-17-0493.

smaller prostates $(<50 \mathrm{~g})$ and those affected by $\mathrm{BPH}$ $(>50 \mathrm{~g})$, the authors found intraprostatic DHT levels correlate with prostate size. Similar results have also been described by others (Olsson et al. 2011, van der Sluis et al. 2012). Comparing ratios of steroids as surrogates of enzymatic activity, there was significant lower in DHT: estrone (E1) ratios in smaller prostates. As seen with prior research (Niu et al. 2011), their results suggest that $\mathrm{BPH}$ is related to greater $5 \alpha$-reductase (5ARI) activity, while smaller prostates may prefer aromatization of testosterone to estrogens. These differences in tissue steroid homeostasis by prostate size are interesting to $\mathrm{PCa}$ progression given that smaller prostate size is known to be an independent predictor of high-grade PCa (Newton et al. 2010).

\section{Relationship between serum and prostate tissue sex steroid levels}

The relationship between circulating and prostate tissue levels of androgens has been addressed in several studies (Bartsch et al. 1986, Miyoshi et al. 2014, Cook et al. 2017, Neuzillet et al. 2017). Overall, intraprostatic levels of DHT and testosterone, as well as dehydroepiandrosterone (DHEA) and androgen metabolites such as androstane-

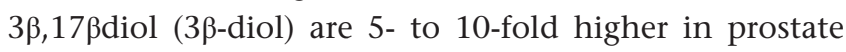
tissue than those in the serum. Recently, Cook and coworkers analyzed the relationship between serum and prostate tissue sex steroids using matched samples from 251 patients undergoing radical prostatectomy for $\mathrm{PCa}$ (Cook et al. 2017). Their analyses demonstrate that serum 
levels of sex steroids were generally poor surrogates for prostatic levels. Nonetheless, there was partial correlation between the individual serum and prostate levels, which was the highest for $3 \beta$-diol glucuronide, followed in order by testosterone, DHT and estrone. Thus, despite being continuously bathed in circulating steroids, prostate sex steroid levels have low correlation with circulating levels in patients with localized PCa.

Further, randomized trials in healthy men suggest that testosterone administration does not significantly alter prostatic androgen levels in the short to mediumterm (Page et al. 2011). For example, Mostaghel and coworkers performed a ten-week study that showed testosterone supplementation induced no change in prostatic androgens compared to placebo, while synthetic estrogen reduced intraprostatic DHT by $40 \%$ (Mostaghel et al. 2012). Overall, neither testosterone nor estrogen administration resulted in significant changes in AR-related gene expression in prostate epithelium. Another study in healthy castrated men examined the impact of exogenous testosterone on intraprostatic androgen levels. In this population, they found exogenous testosterone raised serum levels of both testosterone and DHT and raised intraprostatic testosterone levels. However, no significant changes in intraprostatic DHT, the major androgen in the prostate, were obtained with supplementation (Thirumalai et al. 2016). While removal of the prostate has been associated with decreased serum DHT levels (Olsson et al. 2010), overall, these data suggest tissue-specific regulation of sex steroids occurs within the prostatic milieu, which is partially independent of serum levels.

\section{Sex steroids and prostate cancer carcinogenesis}

It remains an actively investigated question whether serum or tissue sex steroid levels are associated with the development of PCa. Age, ethnicity and obesity play a significant confounding role in understanding this risk. For example, higher body mass index (BMI) is associated with increased serum levels of estrogens as well as larger prostate size (Joseph et al. 2002), while at the same time, estradiol levels, but not testosterone, are higher in African American men compared to Caucasian men (Litman et al. 2006, Rohrmann et al. 2007). The high prevalence of indolent cancer and variable serum PSA thresholds for biopsy are other important confounders. Multiple studies have assessed the role of testosterone levels related to PCa risk. However, the relationship between testosterone or DHT levels, exogenous testosterone and overall PCa risk remains inconsistent in the literature, in part due to low methodological quality (Muller et al. 2012, Klap et al. 2015). The literature does appear to support that lower serum testosterone at diagnosis is associated with more aggressive PCa (Botto et al. 2011, Dai et al. 2012, GarcíaCruz et al. 2012, Park et al. 2016, Llukani et al. 2017). Recently, large drops or large fluctuations of a man's serum testosterone levels in the past were also associated with risk of PCa (Xu et al. 2017). Similarly, low serum DHEA levels were associated with more aggressive localized PCa (Miyoshi et al. 2016). The role of other sex steroids, if any, on PCa prevalence remains unclear. Ecologic studies have raised the question whether estrogens could be related to PCa development, with serum estrone previously linked to PCa risk (Margel \& Fleshner 2011, Kristal et al. 2012). Lower estradiol levels in PCa cases vs controls have also been reported (Schatzl et al. 2000). Careful consideration of confounders, as well as accurate measurement techniques will be crucial to understand if there exists any link between serum sex steroid levels and PCa carcinogenesis.

5ARI inhibitors are known to decrease intraprostatic dihydrotestosterone levels while increasing intraprostatic testosterone (Marks et al. 2001, Mostaghel et al. 2012). The Prostate Cancer Prevention Trial (PCPT) and Reduction by Dutasteride of Prostate Cancer Events (REDUCE) clinical trials successfully demonstrated the ability of finasteride and dutasteride, respectively, to decrease by about $25 \%$ the detection by biopsy of indolent PCa; yet, both studies showed a concomitant $0.5 \%$ absolute increase in highgrade cancer (Thompson et al. 2003, Andriole et al. 2010). Taken together, these studies indicate decreases in prostate tissue androgens by 5ARIs may decrease the prevalence of indolent cancer, but they do not provide sufficient evidence to indicate that changes in serum or prostatic sex steroid levels are related to any increased incidence of high-grade PCa.

\section{Changes in androgens and estrogens following androgen deprivation therapy}

Luteinizing hormone-related hormone (LHRH) agonists and LHRH antagonists function to decrease serum free and total testosterone, with a nadir value generally obtained within the first year (Xu et al. 2002, Gulley et al. 2005, Nishii et al. 2012). In addition, serum adrenal androgens may decrease to a lesser extent following LHRH antagonists (Miyazawa et al. 2017). Studies with orchiectomy or LHRH agonists suggest that DHEA does not change substantially following ADT (Xu et al. 2002, Oka et al. 2003). One study reported that 5 -androstenediol 
levels do not change following castration (Mizokami et al. 2004). However, in men treated with estrogens, a decline in DHEA levels is observed concomitant with increases in sex hormone-binding globulin levels (Aggarwal et al. 2009). The authors also reported that a decline in serum DHEA-sulfate and a rise in DHT are both associated with a PSA response in men treated with estrogens. Following LHRH agonist therapy, estradiol levels typically decrease by about 90\% (Nishii et al. 2012).

In prostate tissue, $\mathrm{ADT}$ is accompanied by a decrease in testosterone and DHT levels, though adrenal androgens may not be significantly altered (Arai et al. 2011). Notably, prostatic testosterone and DHT levels decrease less following ADT compared to non-prostate tissues (van der Sluis et al. 2012). Neoadjuvant prostatectomy studies have evaluated prostate tissue androgens following ADT. For example, Mostaghel and coworkers found that while serum androgens drop by $~ 95 \%$ following ADT, intraprostatic androgens decline by only 70\% (Mostaghel et al. 2007). A neoadjuvant study comparing an LHRH antagonist and LHRH agonist did not suggest the differences in prostate tissue T or DHT between treatments (Sayyid et al. 2017). Another neoadjuvant prostatectomy study clearly established that combinations of LHRH agonist with CYP17 inhibitors or 5ARIs can further lower prostate tissue androgen levels (Mostaghel et al. 2014). While relatively little is known about serum androgen and estrogen levels over time during ADT, the persistence of androgens and metabolites in prostate tissues despite ADT highlights the importance of intratumoral steroidogenesis in sustaining androgen-dependent tumors and thereby contributing to castration resistance.

\section{Changes in serum and prostatic androgens with castration-resistant prostate cancer}

Castration resistance is defined by $\mathrm{PCa}$, which is progressing biochemically, radiologically or clinically despite the presence of castrate serum testosterone levels. Intratumoral synthesis of androgens is a recognized mechanism of castration resistance discussed further below. The extent of intratumoral androgen synthesis appears to increase as PCa progresses to more advanced stages (Montgomery et al. 2008, Efstathiou et al. 2015, Liu et al. 2015). This is supported by analyses demonstrating higher expression of steroidogenic enzymes in bone metastases in men with CRPC compared to primary tumors (Stanbrough et al. 2006, Mitsiades et al. 2012), as well as coincident higher testosterone and DHT levels in metastatic samples (Jernberg et al. 2013). In a cohort of 18 CRPC patients treated with ADT, one study found similar intraprostatic testosterone levels in castrate $\mathrm{PCa}$ patients compared to BPH controls $(0.80 \mathrm{ng} / \mathrm{g}$ testosterone in CRPC tissue vs $0.95 \mathrm{ng} / \mathrm{g}$ in $\mathrm{BPH}$ tissue; $P=0.21$ ), while DHT levels were lower in CRPC than BPH control (Titus et al. 2005). Further, analyses of prostate tissue prior to ADT found that those who progressed to CRPC had higher baseline intraprostatic testosterone and lower DHT (Shibata et al. 2013).

There is only weak data suggesting that serum androgens levels change during CRPC or following CRPC treatments. In the serum of patients developing CRPC, one study suggests the relative T:DHT ratio becomes inverted, with testosterone as the predominant androgen (Montgomery et al. 2008). Another study reports serum testosterone levels increase following 8 weeks of enzalutamide therapy for CRPC (Efstathiou et al. 2015). The increased age of CRPC patients may be a significant confounder in interpreting testosterone levels and may explain why serum testosterone levels were prognostic of survival in men starting abiraterone therapy post chemotherapy (Ryan et al. 2013b).

\section{Genomic alterations implicating sex steroids in prostate cancer progression}

With steroidogenesis implicated in the progression of PCa, multiple studies have assessed the role of single nucleotide polymorphism (SNPs) in genes related to sex steroids on the risk of PCa progression. Differences in serum sex steroids have been reported to vary by ethnicity (Jakobsson et al. 2006, Nadeau et al. 2011, Levesque et al. 2013). It is notable that despite the low prevalence of genetic aberrations in localized prostate cancer, many of these somatic polymorphisms have significant effects on prostate cancer progression and outcome (summarized in Table 1).

Somatic SNPs in androgen transport genes SLCO2B1 and SLCO1B3 are implicated in altering the duration of response to ADT (Wright et al. 2011, Yang et al. 2011, Wang et al. 2016). SLCO2B1 and SLCO1B3 are anionic transporters, which facilitate specific steroids to cross the cell membrane (reviewed in Cho et al. 2014). Expression of SLCO1B3 and SLCO2B1 is higher in metastatic prostate samples compared to localized PCa samples (Wright et al. 2011). SNPs of SLCO1B3 result in increased testosterone transport into cells. These SNPS are associated with both sooner time to CRPC as well as overall survival (Hamada et al. 2008, Sharifi et al. 2008, Yang et al. 2011). Similarly, time to castration resistance has been reported lower 
in men with SNP variants of SLCO2B1 (Fujimoto et al. 2013). These SLCO2B1 variants result in increased DHEA transport into cells. Statins are recognized inhibitors of SLCO2B1 transport and may explain why a longer time to progression for men treated with a statin at the time of ADT initiation was seen in a large cohort of men receiving ADT (Harshman et al. 2015). This was seen in men with and without metastases after adjusting for prognostic factors.

SRD5A1 and SRD5A2 genes encode different isoforms of the $\alpha$-reductase abundant in the prostate, which converts testosterone into the more potent DHT. A meta-analysis concluded that the SRD5A2 rs9282858 polymorphism is associated with increased risk of PCa (Fang et al. 2017). A small Japanese study of 86 patients found that lower serum testosterone levels during ADT were associated with the CC allele in the SRD5A2 gene (rs523349), and this conferred a better prognosis (Shiota et al. 2016). The same group previously also reported that the rs523349 SRD5A2 SNP conferred a worse prognosis for men treated with primary ADT (Shiota et al. 2015). Polymorphisms of SRD5A1 and SRD5A2 have also been associated with recurrence of PCa post-prostatectomy (Audet-Walsh et al. 2011).

In two large independent cohorts, including men on $\mathrm{ADT}$, Levesque and coworkers found that SNP variants in CYP17A1 (rs6162), HSD17B2 (rs4243229 and rs7201637) and ESR1 (rs1062577) were associated with PCa and overall survival (Levesque et al. 2013). Moreover, these SNPs were associated with altered levels of circulating sex steroids. A variant in the CYP11A1 gene has been associated in one study with an increased risk of metastatic PCa (Kumazawa et al. 2004).

HSD3B1 is a key enzyme in the steroidogenic synthesis pathway (Fig. 1). Expression of the 1245C SNP results in increased HSD3B1 protein levels via inhibition of ubiquitin-mediated degradation and subsequently a greater flux toward DHT synthesis (Chang et al. 2013). Heterozygous HSD3B1 variant (1245C) allele has been associated with a shorter time to CRPC in a Chinese cohort of 108 patients where the heterozygote prevalence was $17 \%$ (Wu et al. 2015). In a multicohort Caucasian population, the variant allelic frequency was $29 \%$ (Hearn et al. 2016). Men homozygous for $1245 \mathrm{C}$ variant in this study had non-significantly higher proportions of highstage T3b-T4 disease and high-grade Gleason 8-10 disease and in one cohort significantly higher proportions of N1-positive disease. In all cohorts, progression-free survival was significantly associated with the genotype and decrease according to the number of variant alleles.

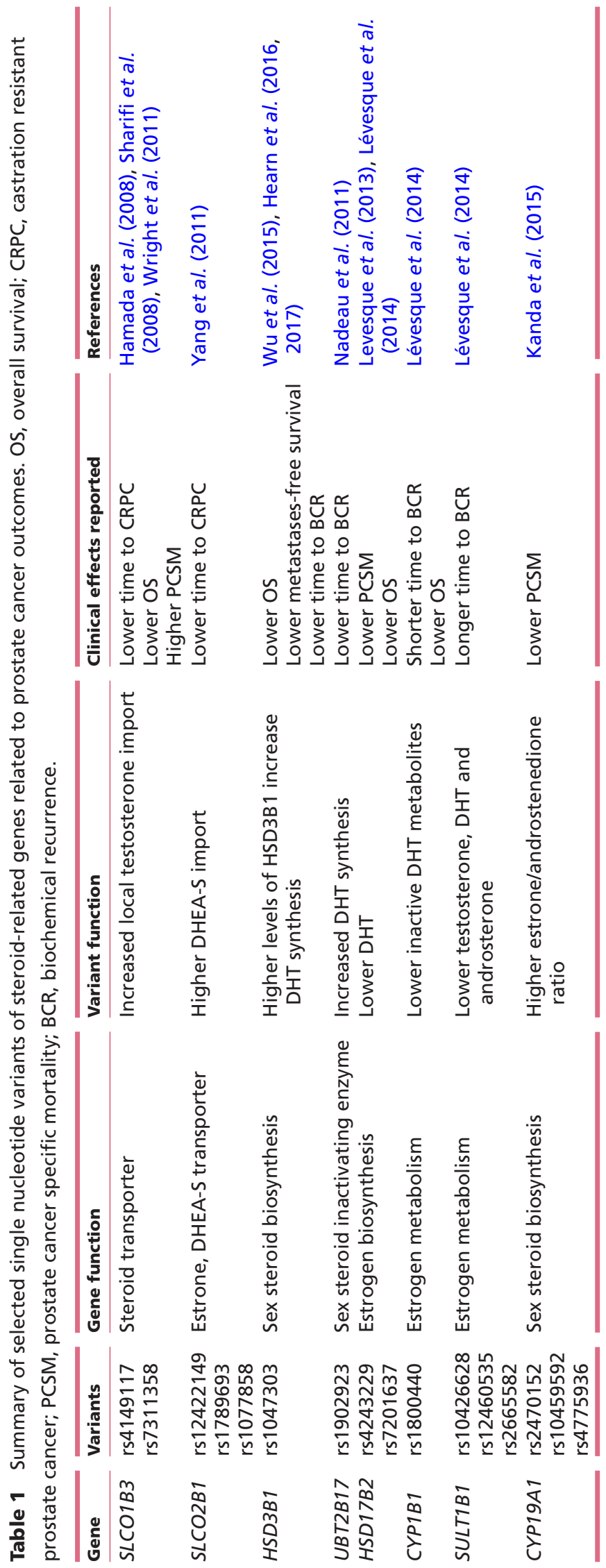


Time to metastases, PCa-specific mortality and overall survival followed similar trends (Hearn et al. 2016). While these post-prostatectomy cohorts were constructed based on eventual use on ADT, a non-selected group of 526 Caucasian patients who underwent radical prostatectomy showed no increased risk of biochemical recurrence with this same SNP (Levesque et al. 2013). Notably, in addition to its germline effects, tumors may acquire this mutation as they progress to resistance (Chang et al. 2013). A recent analysis of 216 men treated with ADT for biochemical recurrence after prostatectomy found that the HSD3B1 1245C variant was associated with shorter time to metastasis, but not time to castration resistance or survival (Hearn et al. 2017). Finally, the $1245 \mathrm{C}$ variant also appears to be a predictor of sensitivity to the steroidal CYP17 inhibitor abiraterone (Almassi et al. 2017).

Genomic variation in estrogen-related genes has also been reported in PCa patients (Lévesque et al. 2014). This includes somatic polymorphisms in CYP1B1, HSD17B2, SULT2B1 and COMT genes. Further, the cumulative number of alterations appears to correlate with poorer outcome (Lévesque et al. 2014). Similarly, SNPs in the CYP19A1 aromatase are associated with concomitant changes in serum estrogen levels and poorer PCa survival, but have no effect on PCa incidence (Travis et al. 2009, Kanda et al. 2015). Increased expression of CYP19A1 has been reported in PCa metastases compared to primary tumors (Cai et al. 2011).

\section{Clinical prognostic value of serum sex steroids as biomarkers in prostate cancer patients}

Multiple studies have sought to address whether serum sex steroids are related to PCa risk or Gleason grade at diagnosis, though the findings have generally been inconsistent to support an association (Severi et al. 2006, Weiss et al. 2008, Sher et al. 2009, Sun et al. 2011). Here, we discuss the role of serum steroids as biomarkers in patients who have potentially lethal PCa for which ADT is indicated.

Following initiation of ADT, higher levels of serum testosterone has been shown in multiple studies to be a biomarker for time to CRPC and PCa-specific survival (Morote et al. 2007, Perachino et al. 2010, Klotz et al. 2015, 2017, Wang et al. 2017a,b). A biological explanation for these findings is lacking, but it is notable that nadir serum testosterone differentiates the development of CRPC years later. Notably, the prognostic value of serum testosterone during ADT appears most useful immediately following treatment initiation, with no reports indicating testosterone values after one year of ADT initiation have prognostic value (Tombal et al. 2017, Wang et al. 2017a,b). One study reported that periodic surges in testosterone may impact progression (Pickles et al. 2012), but this has not been validated in other data sets. The equivalence of intermittent ADT, which results in significantly higher rises in serum testosterone levels, also raises questions about the significance of these findings. However, several small studies have found a correlation between testosterone levels on ADT and PSA values, suggesting that incomplete ADT may fuel cancer cell growth (Takizawa et al. 2010, Kawakami \& Morales 2013).

In CRPC, several studies have evaluated serum testosterone during $\mathrm{ADT}$ as a predictive marker of response to subsequent chemotherapy, abiraterone and enzalutamide. Low testosterone prior to chemotherapy and after chemotherapy prior to abiraterone have been associated with poorer survival (Ryan et al. 2013b, Irelli et al. 2014). In addition to testosterone, lower levels of both androstenedione and DHEA-S were associated with a trend for poorer survival in men post chemotherapy, regardless of treatment arm (Ryan et al. 2013b). Other studies did not show a relationship between circulating sex steroids and response to abiraterone (Kim et al. 2014, Ryan et al. 2014, Bertaglia et al. 2017, McKay et al. 2017).

The prognostic role of serum estrogens is less clear, and their levels may be correlated with androgen levels through peripheral aromatization. A study in the pre-PSA era demonstrated significantly lower serum estrone (as well as bioavailable testosterone) in metastatic patients compared to non-metastatic PCa patients (Eriksson \& Carlström 1988). Another study reported that serum E1, E2 and E1-S were commonly elevated in men with highgrade localized PCa (Giton et al. 2008). Finally, others have reported the estrogen:androgen ratio is inversely related to the risk of aggressive PCa (Black et al. 2014).

\section{Biological effects of sex steroids within the prostate cancer tumor microenvironment}

\section{Androgens}

The intratumoral de novo synthesis of androgens and intratumoral conversion of adrenal precursors to androgens represents areas of significant investigation in PCa over the last decade. Several translational studies now indicate that conversion of circulating precursors represents the most dominant path to intratumoral DHT production. Fankhauser and coworkers compared incubated fresh prostatic tissue obtained via transurethral resection of the prostate and 
analyzed the conversion of radiolabeled steroid precursors in ex vivo cultures. They found that androstenedione was the predominate source of androgens in CRPC tissue (Fankhauser et al. 2014). More recently, another group also used radiolabeled precursors and reported that adrenal androstenedione is the preferred substrate precursor for 5-alpha reduction to DHT in CRPC tissue (Dai et al. 2017). These results differed from localized prostatectomy tissue, suggesting resistant prostate tumors develop capacities to metabolize steroids, which differs from treatment-naive tumors. Finally, a recent analysis of prostate tissue from men who received neoadjuvant leuprolide acetate \pm abiraterone acetate identified that DHEA, epi-androsterone and their metabolites were predominantly of adrenal origin, whereas

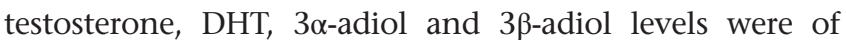
testicular origin (Zang et al. 2017). This intratumoral androgen synthesis results in persistently higher androgen levels in the prostate: while serum androgens drop by 95\% following $\mathrm{ADT}$, intraprostatic androgens decline by only 70\% (Mostaghel et al. 2007).

The presence of androgens within the TME permits continued activation of the AR in PCa cells. Persistent androgen levels following ADT are associated with more aggressive PCa. In localized prostate tumors treated with 6 months of ADT prior to surgery, the relative reduction in prostatic DHT levels was greater in Gleason 6 tumors than Gleason 7-10 tumors (Nishiyama et al. 2007). Men with high grade (Gleason $\geq 8$ ) had higher prostatic testosterone levels than those with Gleason $\leq 6(P=0.06)$ (Nishiyama et al. 2007). Another study of men initiating ADT found serum DHEA-sulfate levels were correlated with Gleason score. PSA values were also correlated with all hormone values at 6 months, but not at baseline (Takizawa et al. 2010). IL-6, which is associated with advanced PCa, has also been linked with serum testosterone and DHEA among men treated with ADT (Chun et al. 2009, Komatsu et al. 2012). Steroidogenesis is higher in metastatic lesions, and this may also be stimulated by osteoclasts or extravesicle transport of CYP17 (Locke et al. 2009, Jernberg et al. 2013, Hagberg Thulin et al. 2016). Reactive, inflamed prostatic stroma may also increase the synthesis of steroidogenic enzymes, which may in turn facilitate intratumoral androgen synthesis from circulating DHEA (Piao et al. 2013).

\section{Estrogen and progesterone}

The effects of estrogens within the PCa microenvironment remain to be fully elucidated. The importance of estrogen receptors $\mathrm{ER} \alpha$ and $\mathrm{ER} \beta$ in PCa are reviewed elsewhere. Older studies implied that stromal actions of androgen and estrogens act in a paracrine manner to induce carcinogenesis via AR or Er $\alpha$ (Bosland 2000, Bosland $\&$ Mahmoud 2011). Studies in rat models demonstrate the combination of testosterone and estradiol, but not testosterone alone, induce prostatic cancer in $100 \%$ of rats (Noble 1977). ER $\beta$ is expressed mainly in prostate epithelial cells, but during development, may be found in both epithelium and stroma. The conversion of testosterone to estradiol within the prostate appears important, as suggested by aromatase knockout mice abrogating the induction of prostatic intraepithelial neoplasia by testosterone and estradiol treatment (Ricke et al. 2008).

In humans, comparison of microdissected $\mathrm{PCa}$ to benign tissue showed elevated expression of ER $\beta$ (Walton et al. 2009). ER $\beta$ appears only in human prostate epithelium, while ER $\alpha$ is found predominantly in the stromal compartment (Lau \& To 2016). In prostatectomy specimens, higher ER $\alpha$ levels in tumor stroma predicted better PCa survival, while higher ER $\beta$ levels in stroma predicted sooner biochemical recurrence. Tissue aromatase levels in both epithelium and stroma were associated with longer time to biochemical recurrence or disease progression (Grindstad et al. 2016). Increased expression of aromatase has been reported in periprostatic adipose tissue, PCa cells and particularly metastatic CRPC (Hiramatsu et al. 1997, Ellem et al. 2004, Takase et al. 2006, Montgomery et al. 2008, Celhay et al. 2010). Prior clinical trials of aromatase inhibitors in PCa patients showed no benefit (Santen et al. 2001, Smith et al. 2002). Compared to Caucasian controls, African Americans have higher serum estradiol levels and high ER $\beta$ gene expression in their tumors, suggesting this may account in part for racial differences in tumor aggressivity (Rohrmann et al. 2007, Abd Elmageed et al. 2013).

The role of progesterone in the prostate TME is less clear. Its expression in microdissected PCa is lower than controls (Walton et al. 2009). In patients treated with abiraterone, accumulation of progesterone results in the selection for mutant, progesterone-activated AR clones (Chen et al. 2014). Similar to $E R \alpha$, preclinical studies suggest it is the stromal PR, which is important to mediate the effects of progesterone within the TME, with the role of epithelial ER and PR in PCa progression unclear (Hobisch et al. 1997, Latil et al. 2001, Yu et al. 2013). 


\section{Sex steroids and the immune tumor microenvironment}

\section{Effect of androgens and estrogens on innate immunity}

Local levels of sex steroids may alter the function of resident immune cells within the TME (Fig. 2). Indeed, differences in the immune system between sexes are largely attributable to differences in exposure to sex steroids (Trigunaite et al. 2015). The function of the immune system also changes with age, and this may be relevant to the increased incidence of prostate cancer in elderly men. The immunoreactivity of antigen-presenting cells (APCs) such as macrophages in the prostate TME is

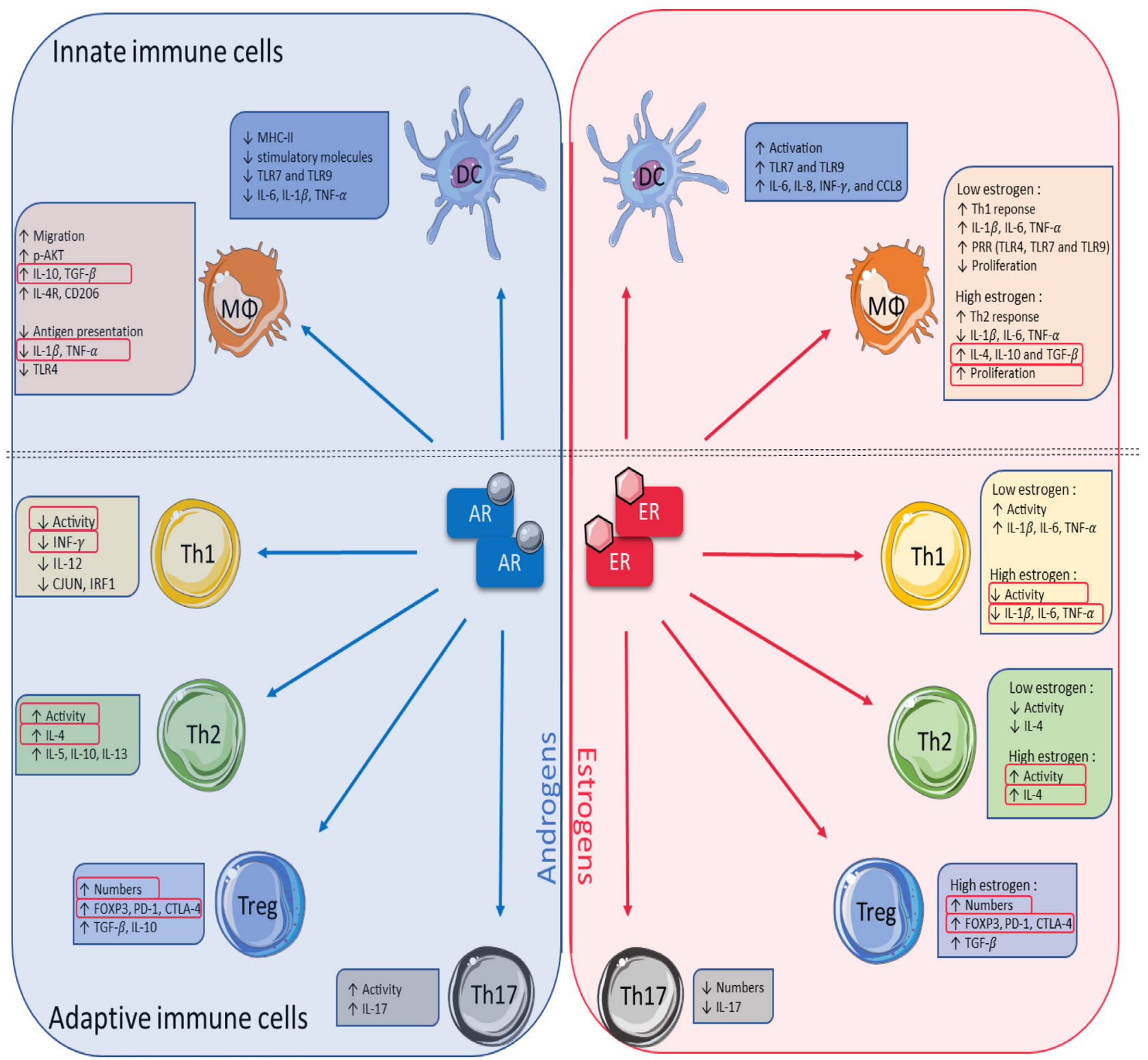

Figure 2

Effects of sex steroid hormones on innate and adaptive immune cells. Androgens (including testosterone) and estrogens (including $17 \beta$-oestradiol) are key components of observed sex differences in immune function. Changes of the levels of these sex steroids may influence various immune cells in their activity, recruitment or cytokine secretion in human, animals or primary cell culture. In general, testosterone is considered as an anti-inflammatory while estrogens are more proinflammatory, but several studies show shared effects on immune cells between hormones (indicated in red). References not cited in text: androgens on T helper cells (Sutherland et al. 2005, Hepworth et al. 2010, Fijak et al. 2011, Andersson et al. 2015, Wang et al. 2017b) and on DCs (Koh et al. 2009, Corrales et al. 2012); estrogens on T helper cells (Correale et al. 1998, Maret et al. 2003, Lélu et al. 2011, Morse \& McNeel 2012, Chen et al. 2015) and on DCs (Zhang et al. 2004). CCL, CC-chemokine ligand; CXCL, CXC-chemokine ligand; DCs, dendritic cells; M $\Phi$, macrophages; IFN, interferon; IL, interleukin; TGF $\beta$, transforming growth factor- $\beta$; Th, helper; TLR, Toll-like receptor; TNF, tumor necrosis factor; Treg, regulatory T cell. Macrophage images reproduced from https://smart.servier.com under the terms of the original Creative Commons license. 
linked to patient outcomes (Ylitalo et al. 2016, Strömvall et al. 2017), emphasizing the importance of understanding this biology. The receptor and non-receptor-mediated effects of steroids on innate immune cells have been widely studied in experimental animal models as well as in clinical studies of many diseases (Trigunaite et al. 2015, Roved et al. 2017). Overall, androgens appear to favor the development of an immunosuppressive state, while estrogens and progesterone may have dose-varying effects on immune function. The impact of the steroidal milieu on the local immune function in prostate tumors is not clearly understood, but may contribute to its typical immunologically 'cold' phenotype.

Estrogens have been shown to promote the expression of HLA-DR and co-stimulating molecules in APCs (Jarrossay \& Thelen 2013). Further, innate immune responses are regulated through the function of pattern recognition receptors (PRRs) on innate immune cells, and these differ by the sex (Bouman et al. 2005, Meier et al. 2009). For example, induction of TLR7 signaling causes higher production of interferon- $\alpha$ in women than that in men (Griesbeck et al. 2015). Spitzer and coworkers previously described the higher phagocytic activity of APCs in women with lupus compared to affected men (Spitzer 1999). Estradiol appears to exert dose-dependent effects on macrophages, with low doses favoring the production of inflammatory cytokines (IL-1 $\beta$, IL-6 and TNF- $\alpha$ ) and high concentrations favoring decreased levels (D'Agostino et al. 1999, Bouman et al. 2005). This is mediated via ER $\alpha$ and the nuclear factor kappa B pathway crosstalk (Härkönen \& Väänänen 2006, Campbell et al. 2014). Pre-clinical studies suggest that estrogens may induce differentiation in dendritic cells and favor inflammatory cytokine expression (Bengtsson et al. 2004). However, studies in other models and in neutrophils suggest an anti-inflammatory influence (Cai et al. 2012).

Androgens in the TME may act via the AR, which is expressed in many innate immune cells, including monocytes and macrophages (Ahmadi \& McCruden 2006). Testosterone has been shown to suppress inflammatory cytokine production by human macrophages (Corrales et al. 2009, Corcoran et al. 2010). In vitro, testosterone decreases the synthesis of proinflammatory cytokines such as TNF- $\alpha$, IL- $1 \beta$ and IL- 6 in macrophages and increases the secretion of CCL17 and CCL22 (D'Agostino et al. 1999). Other studies suggest that testosterone may diminish PRR toll-like receptor 4 (TLR4) expression, which is involved in polarizing macrophages to an inflammatory phenotype (Rettew et al. 2008). Cellular signaling studies indicate that testosterone regulates macrophage polarization through the inhibitory regulative Goi-protein and Akt phosphorylation, but not via AR (Ren et al. 2017). Finally, androgens appear to decrease the function of neutrophils by diminution of secretion of the chemoattractant CXCL8 (Pioli et al. 2007).

\section{Effect of androgens and estrogens on immunoregulatory and effector cells}

While the innate immune response helps coordinate the body's response to cancer, immunoregulatory and effector $\mathrm{T}$ cells are also important in the prostate TME. The T cell response is categorized in four distinct subtypes based on transcriptional factors, cytokine production and function. The IFN- $\gamma$-dominant $\mathrm{T}$ cell response is called Th1, while the IL-4 dominant response is called Th2; Th17 secretes the bi-functional cytokine IL-17 and regulatory $\mathrm{T}$ cells (Treg) secrete anti-inflammatory cytokines such as IL-10 and TGF $\beta$.

Emerging evidence suggests estrogens may alter T cell function to favor an anti-inflammatory response, but this response is concentration dependent. A Th1 response is generally by low doses of $\mathrm{E} 2$, whereas high doses promote a Th2 response. Others have shown estrogens may mediate a reduction in IL- 6 secretion and STAT3 activity. Interestingly, estrogen upregulates the expression of IL-10, CTLA4 and PD-1 in regulatory T cells, and mice treated with ER antagonist show a reduction of suppressive CD4+ CD25+ Treg activity (Polanczyk et al. 2004, 2007). The effect of estrogens on PCa-associated immunoregulatory cells is unclear. It appears that estradiol levels within the TME may stimulate MDSCs via ER $\alpha$ signaling, activating their tumor-promoting features. Ellem and coworkers described increased inflammation-related prostatic changes in detail using a murine model of aromatase gene overexpression (Ellem et al. 2004). Rat studies have also suggested estrogens are important to PCa carcinogenesis (Bosland \& Mahmoud 2011). Androgens are known to suppress the activity of these immune cells (Kovats et al. 2010). Mechanisms include increasing the synthesis of anti-inflammatory cytokine mediators such as IL-10 and direct repression of nuclear factor $\kappa \mathrm{B}$ (NF-кB), cJun and IRF1 or IL-12 secretion (Olsen \& Kovacs 1996, Liva \& Voskuhl 2001, Dunn et al. 2007, Kissick et al. 2014). It was shown in both murine and human models that androgens inhibit the polarization of Th-1 lymphocytes via the reduction of phosphorylation of the STAT4. Similarly, it was shown that Th2 lymphocytes are capable to produce steroids, decreasing the proliferation of T-helper cells and stimulating Treg production. Accordingly, androgen 
deficiency in men results in a higher ratio of CD4 to CD8 $\mathrm{T}$ cells, with an increase of proinflammatory cytokines (IL-1B, IL-2 and TNF- $\alpha$ ) and decreased Tregs (Musabak et al. 2003, Roden et al. 2004, Page et al. 2006). Further, a higher number of myeloid-derived suppressor cells (MDSCs) have been correlated with ADT use, through the effect of androgens on regulating MDSCs or Tregs is not clear (Vuk-Pavlović et al. 2010, Brusa et al. 2013, Davidsson et al. 2013, Di Mitri et al. 2014, Lu et al. 2017, Svoronos et al. 2017). ADT initiation has recently been demonstrated to initiate infiltration of inflammatory $\mathrm{T}$ cells in the Myc-CaP prostate cancer model; the induced inflammation then decreases over time. Similar to MDSCs, it remains unclear whether relative castration levels of androgens may alter the function of $\mathrm{T}$ cells, though some data suggest a correlation between androgen levels and regulatory $\mathrm{T}$ cell function.

Taken together, these studies, mostly in non-cancer models suggest that sex steroids may have an influence on the function of innate, regulatory and effector immune cells in the prostate microenvironment. An understanding of this biology may assist in the rationale development of immunotherapies for PCa patients and help identify potential biomarkers of response to immunotherapy in PCa patients.

\section{Conclusion and future directions}

The hormonal milieu within the prostate TME is tightly regulated and changes throughout $\mathrm{PCa}$ progression to resistance. It is also influenced by circulating and androgen precursors and circulating estrogens. While steroidogenesis is very complex, it nonetheless appears that phenotypes defined by levels of sex steroids or somatic genotype may be used to classify patients at risk of progression. However, the context is clearly important, with the utility of both biomarkers different before and after treatment.

As treatment of advanced PCa becomes increasingly complex with multiple treatments available, understanding the underlying biology becomes increasingly important to best match patients with effective treatments. For example, while androgen synthesis with abiraterone is broadly used, there remains to be clearly defined phenotypes, which best respond (or do not respond) to this treatment. Defining this phenotype in both castrate sensitive and CRPC tumors remains a priority. A better understanding of the cellular effects of sex steroids within the TME may thus facilitate rational approaches to combination therapies based on patient and tumor biology. Whether these phenotypes are best defined by tumor or host characteristics remains an open question. Given the critical roles local sex steroids play in PCa progression, accurately understanding different hormonal phenotypes may assist with personalizing treatments and utilizing rational combination therapies in patients at higher risk of progression. This includes potential combinations of AR-targeted agents with novel immunotherapies. For example, understanding the effects of androgens on APCs and immunoregulatory cells may be important to best select patients and devise combination strategies for checkpoint inhibitor therapy in PCa patients. Finally, the relationship between phenotypes defined by tumoral microenvironment factors, such as immunoreactivity and sex steroids levels and genomic classification of tumors also remains relatively unexplored. An understanding of these areas has high potential to impact patient outcomes by providing a biological framework for more effective use of existing treatments and more effective integration of novel treatments.

\section{Declaration of interest}

$\mathrm{C}$ Boibessot has no potential conflict of interest to disclose. $\mathrm{P}$ Toren reports research funding from Innocrin Pharmaceuticals, personal fees from Ferring, Sanofi Canada, Astellas and Abbvie unrelated to this review article.

\section{Funding}

This work was funded by the Fonds de Recherche du Québec - Santé clinician-scientist award (\#32774) and a Prostate Cancer Canada Movember Discovery Grant (D2016-1393).

\section{References}

Abd Elmageed ZY, Moroz K, Srivastav SK, Fang Z, Crawford BE, Moparty K, Thomas R \& Abdel-Mageed AB 2013 High circulating estrogens and selective expression of ER $\beta$ in prostate tumors of Americans: implications for racial disparity of prostate cancer. Carcinogenesis 34 2017-2023. (https://doi.org/10.1093/carcin/bgt156) Aggarwal R, Weinberg V, Small EJ, Oh W, Rushakoff R \& Ryan CJ 2009 The mechanism of action of estrogen in castration-resistant prostate cancer: clues from hormone levels. Clinical Genitourinary Cancer $\mathbf{7}$ E71-E76. (https://doi.org/10.3816/CGC.2009.n.027)

Ahmadi K \& McCruden AB 2006 Macrophage may responses to androgen via its receptor. Medical Science Monitor 12 BR15-BR20.

Almassi N, Reichard C, Li J, Russell C, Perry J, Ryan CJ, Friedlander T \& Sharifi N 2017 HSD3B1 and response to a nonsteroidal CYP17A1 inhibitor in castration-resistant prostate cancer. JAMA Oncology [epub]. (https://doi.org/10.1001/jamaoncol.2017.3159)

Andersson A, Grahnemo L, Engdahl C, Stubelius A, Lagerquist MK, Carlsten H \& Islander U 2015 IL-17-producing $\gamma \delta$ T cells are regulated by estrogen during development of experimental arthritis. Clinical Immunology 161 324-332. (https://doi.org/10.1016/j. clim.2015.09.014) 
Andriole GL, Bostwick DG, Brawley OW, Gomella LG, Marberger M, Montorsi F, Pettaway CA, Tammela TL, Teloken C, Tindall DJ, et al. 2010 Effect of dutasteride on the risk of prostate cancer. New England Journal of Medicine 362 1192-1202. (https://doi.org/10.1056/ NEJMoa0908127)

Arai S, Miyashiro Y, Shibata Y, Tomaru Y, Kobayashi M, Honma S \& Suzuki K 2011 Effect of castration monotherapy on the levels of adrenal androgens in cancerous prostatic tissues. Steroids $\mathbf{7 6}$ 301-308. (https://doi.org/10.1016/j.steroids.2010.12.001)

Araujo AB, O’Donnell AB, Brambilla DJ, Simpson WB, Longcope C, Matsumoto AM \& McKinlay JB 2004 Prevalence and incidence of androgen deficiency in middle-aged and older men: estimates from the Massachusetts Male Aging Study. Journal of Clinical Endocrinology and Metabolism 89 5920-5926. (https://doi.org/10.1210/jc.2003031719)

Audet-Walsh E, Bellemare J, Nadeau G, Lacombe L, Fradet Y, Fradet V, Huang S-P, Bao B-Y, Douville P, Girard H, et al. 2011 SRD5A polymorphisms and biochemical failure after radical prostatectomy. European Urology 60 1226-1234. (https://doi.org/10.1016/j. eururo.2011.06.020)

Bartsch W, Kozák I, Gorenflos P, Becker H \& Voigt KD 1986 Concentrations of 3 beta-hydroxy androgens in epithelium and stroma of benign hyperplastic and normal human prostate. Prostate 8 3-10. (https://doi.org/10.1002/pros.2990080103)

Bélanger A, Dupont A \& Labrie F 1984 Inhibition of basal and adrenocorticotropin-stimulated plasma levels of adrenal androgens after treatment with an antiandrogen in castrated patients with prostatic cancer. Journal of Clinical Endocrinology and Metabolism 59 422-426. (https://doi.org/10.1210/jcem-59-3-422)

Bengtsson AK, Ryan EJ, Giordano D, Magaletti DM \& Clark EA 2004 17beta-Estradiol (E2) modulates cytokine and chemokine expression in human monocyte-derived dendritic cells. Blood 104 1404-1410. (https://doi.org/10.1182/blood-2003-10-3380)

Bertaglia V, Tucci M, Vignani F, Buttigliero C, Aroasio E, Berruti A, Scagliotti GV \& Di Maio M 2017 An exploratory analysis of the association between levels of hormones implied in steroid biosynthesis and activity of abiraterone in patients with metastatic castration-resistant prostate cancer. Minerva Urologica e Nefrologica 69 349-358. (https://doi.org/10.23736/S0393-2249.16.02746-6)

Black A, Pinsky PF, Grubb RL, Falk RT, Hsing AW, Chu L, Meyer T, Veenstra TD, Xu X, Yu K, et al. 2014 Sex steroid hormone metabolism in relation to risk of aggressive prostate cancer. Cancer Epidemiology, Biomarkers and Prevention 23 2374-2382. (https://doi. org/10.1158/1055-9965.EPI-14-0700)

de Bono JS, Logothetis CJ, Molina A, Fizazi K, North S, Chu L, Chi KN, Jones RJ, Goodman OB Jr, Saad F, et al. 2011 Abiraterone and increased survival in metastatic prostate cancer. New England Journal of Medicine 364 1995-2005. (https://doi.org/10.1056/ NEJMoa1014618)

Bosland MC 2000 The role of steroid hormones in prostate carcinogenesis. Journal of the National Cancer Institute Monographs 2000 39-66. (https://doi.org/10.1093/oxfordjournals. jncimonographs.a024244)

Bosland MC \& Mahmoud AM 2011 Hormones and prostate carcinogenesis: androgens and estrogens. Journal of Carcinogenesis $\mathbf{1 0}$ 33. (https://doi.org/10.4103/1477-3163.90678)

Botto H, Neuzillet Y, Lebret T, Camparo P, Molinie V \& Raynaud JP 2011 High incidence of predominant Gleason pattern 4 localized prostate cancer is associated with low serum testosterone. Journal of Urology 186 1400-1405. (https://doi.org/10.1016/j.juro.2011.05.082)

Bouman A, Heineman MJ \& Faas MM 2005 Sex hormones and the immune response in humans. Human Reproduction Update 11 411-423. (https://doi.org/10.1093/humupd/dmi008)

Brusa D, Simone M, Gontero P, Spadi R, Racca P, Micari J, Degiuli M, Carletto S, Tizzani A \& Matera L 2013 Circulating immunosuppressive cells of prostate cancer patients before and after radical prostatectomy: profile comparison. International Journal of Urology 20 971-978. (https://doi.org/10.1111/iju.12086)

Cai C, Chen S, Ng P, Bubley GJ, Nelson PS, Mostaghel EA, Marck B, Matsumoto AM, Simon NI, Wang H, et al. 2011 Intratumoral de novo steroid synthesis activates androgen receptor in castrationresistant prostate cancer and is upregulated by treatment with CYP17A1 inhibitors. Cancer Research 71 6503-6513. (https://doi. org/10.1158/0008-5472.CAN-11-0532)

Cai Y, Zhou J \& Webb DC 2012 Estrogen stimulates Th2 cytokine production and regulates the compartmentalisation of eosinophils during allergen challenge in a mouse model of asthma. International Archives of Allergy and Immunology 158 252-260. (https://doi. org/10.1159/000331437)

Campbell L, Emmerson E, Williams H, Saville CR, Krust A, Chambon P, Mace KA \& Hardman MJ 2014 Estrogen receptor-alpha promotes alternative macrophage activation during cutaneous repair. Journal of Investigative Dermatology 134 2447-2457. (https://doi.org/10.1038/ jid.2014.175)

Celhay O, Yacoub M, Irani J, Dore B, Cussenot O \& Fromont G 2010 Expression of estrogen related proteins in hormone refractory prostate cancer: association with tumor progression. Journal of Urology 184 2172-2178. (https://doi.org/10.1016/j. juro.2010.06.089)

Chang KH, Li R, Kuri B, Lotan Y, Roehrborn CG, Liu JY, Vessella R, Nelson PS, Kapur P, Guo XF, et al. 2013 A gain-of-function mutation in DHT synthesis in castration-resistant prostate cancer. Cell $\mathbf{1 5 4}$ 1074-1084. (https://doi.org/10.1016/j.cell.2013.07.029)

Chen E, Sowalsky AG, Gao S, Cai C, Voznesensky O, Schaefer R, Loda M, True LD, Ye H, Troncoso P, et al. 2014 Abiraterone treatment in castration-resistant prostate cancer selects for progesterone responsive mutant androgen receptors. Clinical Cancer Research 21 1273-1280. (https://doi.org/10.1158/1078-0432.CCR-14-1220)

Chen R-Y, Fan Y-M, Zhang Q, Liu S, Li Q, Ke G-L, Li C \& You Z 2015 Estradiol inhibits Th17 cell differentiation through inhibition of ROR $\gamma \mathrm{T}$ transcription by recruiting the ER $\alpha /$ REA complex to estrogen response elements of the ROR $\gamma \mathrm{T}$ promoter. Journal of Immunology 194 4019-4028. (https://doi.org/10.4049/jimmunol.1400806)

Cho E, Montgomery RB \& Mostaghel EA 2014 Minireview: SLCO and ABC transporters: a role for steroid transport in prostate cancer progression. Endocrinology 155 4124-4132. (https://doi.org/10.1210/ en.2014-1337)

Chun JY, Nadiminty N, Dutt S, Lou W, Yang JC, Kung HJ, Evans CP \& Gao AC 2009 Interleukin-6 regulates androgen synthesis in prostate cancer cells. Clinical Cancer Research 15 4815-4822. (https://doi. org/10.1158/1078-0432.ccr-09-0640)

Cook MB, Stanczyk FZ, Wood SN, Pfeiffer RM, Hafi M, Veneroso CC, Lynch B, Falk RT, Zhou CK, Niwa S, et al. 2017 Relationships between circulating and intraprostatic sex steroid hormone concentrations. Cancer Epidemiology, Biomarkers and Prevention 26 1660-1666. (https://doi.org/10.1158/1055-9965.EPI-17-0215)

Corcoran MP, Meydani M, Lichtenstein AH, Schaefer EJ, Dillard A \& Lamon-Fava S 2010 Sex hormone modulation of proinflammatory cytokine and C-reactive protein expression in macrophages from older men and postmenopausal women. Journal of Endocrinology 206 217-224. (https://doi.org/10.1677/JOE-10-0057)

Corrales JJ, Almeida M, Miralles JM \& Orfao A 2009 Persistence of androgenic effects on the production of proinflammatory cytokines by circulating antigen-presenting cells after withdrawal of testosterone treatment in aging type 2 diabetic men with partial androgen deficiency. Fertility and Sterility 92 311-319. (https://doi org/10.1016/j.fertnstert.2008.05.040)

Corrales JJ, Almeida M, Cordero M, Martín-Martín L, Méndez C, Miralles JM \& Orfao A 2012 Enhanced immunological response by dendritic cells in male hypogonadism: immunoenhancing in male hypogonadism. European Journal of Clinical Investigation 42 1205-1212. (https://doi.org/10.1111/j.1365-2362.2012.02712.x)
(2) 2018 Society for Endocrinology Published by Bioscientifica Ltd. Printed in Great Britain 
Correale J, Arias M \& Gilmore W 1998 Steroid hormone regulation of cytokine secretion by proteolipid protein-specific CD4+ T cell clones isolated from multiple sclerosis patients and normal control subjects. Journal of Immunology 161 3365-3374.

D’Agostino P, Milano S, Barbera C, Di Bella G, La Rosa M, Ferlazzo V, Farruggio R, Miceli DM, Miele M, Castagnetta L, et al. 1999 Sex hormones modulate inflammatory mediators produced by macrophages. Annals of the New York Academy of Sciences $\mathbf{8 7 6}$ 426-429.

Dai B, Qu Y, Kong Y, Ye D, Yao X, Zhang S, Wang C, Zhang H \& Yang W 2012 Low pretreatment serum total testosterone is associated with a high incidence of Gleason score 8-10 disease in prostatectomy specimens: data from ethnic Chinese patients with localized prostate cancer. BJU International 110 E667-E672. (https://doi. org/10.1111/j.1464-410X.2012.11465.x)

Dai C, Chung Y-M, Kovac E, Zhu Z, Li J, Magi-Galluzzi C, Stephenson AJ, Klein EA \& Sharifi N 2017 Direct metabolic interrogation of dihydrotestosterone biosynthesis from adrenal precursors in primary prostatectomy tissues. Clinical Cancer Research 23 6351-6362. (https://doi.org/10.1158/1078-0432.CCR-17-1313)

Davidsson S, Ohlson A-L, Andersson S-O, Fall K, Meisner A, Fiorentino M, Andrén O \& Rider JR 2013 CD4 helper T cells, CD8 cytotoxic T cells, and FOXP3(+) regulatory T cells with respect to lethal prostate cancer. Modern Pathology 26 448-455. (https://doi. org/10.1038/modpathol.2012.164)

Di Mitri D, Toso A, Chen JJ, Sarti M, Pinton S, Jost TR, D'Antuono R, Montani E, Garcia-Escudero R, Guccini I, et al. 2014 Tumourinfiltrating Gr-1+ myeloid cells antagonize senescence in cancer. Nature 515 134-137. (https://doi.org/10.1038/nature13638)

Dunn SE, Ousman SS, Sobel RA, Zuniga L, Baranzini SE, Youssef S, Crowell A, Loh J, Oksenberg J \& Steinman L 2007 Peroxisome proliferator-activated receptor (PPAR)alpha expression in T cells mediates gender differences in development of T cell-mediated autoimmunity. Journal of Experimental Medicine 204 321-330. (https://doi.org/10.1084/jem.20061839)

Efstathiou E, Titus M, Wen S, Hoang A, Karlou M, Ashe R, Tu SM, Aparicio A, Troncoso P, Mohler J, et al. 2015 Molecular characterization of enzalutamide-treated bone metastatic castrationresistant prostate cancer. European Urology 67 53-60. (https://doi. org/10.1016/j.eururo.2014.05.005)

Ellem SJ, Schmitt JF, Pedersen JS, Frydenberg M \& Risbridger GP 2004 Local aromatase expression in human prostate is altered in malignancy. Journal of Clinical Endocrinology and Metabolism 89 2434-2441. (https://doi.org/10.1210/jc.2003-030933)

Eriksson A \& Carlström K 1988 Prognostic value of serum hormone concentrations in prostatic cancer. Prostate 13 249-256. (https://doi. org/10.1002/pros.2990130307)

Fang C, Guo Z-Q, Chen X-Y, Liu T-Z, Zeng X-T \& Wang X-H 2017 Relationship between SRD5A2 rs9282858 polymorphism and the susceptibility of prostate cancer: a meta-analysis based on 20 publications. Medicine 96 e6791. (https://doi.org/10.1097/ MD.0000000000006791)

Fankhauser M, Tan Y, Macintyre G, Haviv I, Hong MK, Nguyen A, Pedersen JS, Costello AJ, Hovens CM \& Corcoran NM 2014 Canonical androstenedione reduction is the predominant source of signaling androgens in hormone-refractory prostate cancer. Clinical Cancer Research 20 5547-5557. (https://doi.org/10.1158/1078-0432. CCR-13-3483)

Fijak M, Schneider E, Klug J, Bhushan S, Hackstein H, Schuler G, Wygrecka M, Gromoll J \& Meinhardt A 2011 Testosterone replacement effectively inhibits the development of experimental autoimmune orchitis in rats: evidence for a direct role of testosterone on regulatory $\mathrm{T}$ cell expansion. Journal of Immunology 186 5162-5172. (https://doi.org/10.4049/jimmunol.1001958)

Fujimoto N, Kubo T, Inatomi H, Bui HTT, Shiota M, Sho T \& Matsumoto T 2013 Polymorphisms of the androgen transporting gene SLCO2B1 may influence the castration resistance of prostate cancer and the racial differences in response to androgen deprivation. Prostate Cancer and Prostatic Diseases 16 336-340. (https://doi.org/10.1038/pcan.2013.23)

García-Cruz E, Piqueras M, Huguet J, Peri L, Izquierdo L, Musquera M, Franco A, Alvarez-Vijande R, Ribal MJ \& Alcaraz A 2012 Low testosterone levels are related to poor prognosis factors in men with prostate cancer prior to treatment. BJU International 110 E541-E546. (https://doi.org/10.1111/j.1464-410X.2012.11232.x)

Giton F, de la Taille A, Allory Y, Galons H, Vacherot F, Soyeux P, Abbou CC, Loric S, Cussenot O, Raynaud J-P, et al. 2008 Estrone sulfate (E1S), a prognosis marker for tumor aggressiveness in prostate cancer (PCa). Journal of Steroid Biochemistry and Molecular Biology 109 158-167. (https://doi.org/10.1016/j. jsbmb.2007.10.005)

Griesbeck M, Ziegler S, Laffont S, Smith N, Chauveau L, Tomezsko P, Sharei A, Kourjian G, Porichis F, Hart M, et al. 2015 Sex differences in plasmacytoid dendritic cell levels of IRF5 drive higher IFN- $\alpha$ production in women. Journal of Immunology 195 5327-5336. (https://doi.org/10.4049/jimmunol.1501684)

Grindstad T, Skjefstad K, Andersen S, Ness N, Nordby Y, Al-Saad S, Fismen S, Donnem T, Khanehkenari MR, Busund L-T, et al. 2016 Estrogen receptors $\alpha$ and $\beta$ and aromatase as independent predictors for prostate cancer outcome. Scientific Reports 6 33114. (https://doi. org/10.1038/srep33114)

Gulley JL, Figg WD, Steinberg SM, Carter J, Sartor O, Higano CS, Petrylak DP, Chatta G, Hussain MH \& Dahut WL 2005 A prospective analysis of the time to normalization of serum androgens following 6 months of androgen deprivation therapy in patients on a randomized phase III clinical trial using limited hormonal therapy. Journal of Urology 173 1567-1571. (https://doi.org/10.1097/01. ju.0000154780.72631.85)

Hagberg Thulin M, Nilsson ME, Thulin P, Ceraline J, Ohlsson C, Damber JE \& Welen K 2016 Osteoblasts promote castration-resistant prostate cancer by altering intratumoral steroidogenesis. Molecular and Cellular Endocrinology 422 182-191. (https://doi.org/10.1016/j. mce.2015.11.013)

Hamada A, Sissung T, Price DK, Danesi R, Chau CH, Sharifi N, Venzon D, Maeda K, Nagao K, Sparreboom A, et al. 2008 Effect of SLCO1B3 haplotype on testosterone transport and clinical outcome in Caucasian patients with androgen-independent prostatic cancer. Clinical Cancer Research 14 3312-3318. (https://doi. org/10.1158/1078-0432.CCR-07-4118)

Härkönen PL \& Väänänen HK 2006 Monocyte-macrophage system as a target for estrogen and selective estrogen receptor modulators. Annals of the New York Academy of Sciences 1089 218-227. (https://doi.org/10.1196/annals.1386.045)

Harshman LC, Wang X, Nakabayashi M, Xie W, Valenca L, Werner L, Yu Y, Kantoff AM, Sweeney CJ, Mucci LA, et al. 2015 Statin use at the time of initiation of androgen deprivation therapy and time to progression in patients with hormone-sensitive prostate cancer. JAMA Oncology 1 495-504. (https://doi.org/10.1001/ jamaoncol.2015.0829)

Hearn JWD, AbuAli G, Reichard CA, Reddy CA, Magi-Galluzzi C, Chang K-H, Carlson R, Rangel L, Reagan K, Davis BJ, et al. 2016 HSD3B1 and resistance to androgen-deprivation therapy in prostate cancer: a retrospective, multicohort study. Lancet Oncology 17 1435-1444. (https://doi.org/10.1016/S1470-2045(16)30227-3)

Hearn JWD, Xie W, Nakabayashi M, Almassi N, Reichard CA, Pomerantz M, Kantoff PW \& Sharifi N 2017 Association of HSD3B1 genotype with response to androgen-deprivation therapy for biochemical recurrence after radiotherapy for localized prostate cancer. JAMA Oncology [epub]. (https://doi.org/10.1001/ jamaoncol.2017.3164)

Hepworth MR, Hardman MJ \& Grencis RK 2010 The role of sex hormones in the development of Th2 immunity in a gender-biased (c) 2018 Society for Endocrinology Published by Bioscientifica Ltd. Printed in Great Britain 
model of Trichuris muris infection. European Journal of Immunology 40 406-416. (https://doi.org/10.1002/eji.200939589)

Hiramatsu M, Maehara I, Ozaki M, Harada N, Orikasa S \& Sasano H 1997 Aromatase in hyperplasia and carcinoma of the human prostate. Prostate 31 118-124. (https://doi.org/10.1002/(SICI)10970045(19970501)31:2<118::AID-PROS7>3.0.CO;2-J)

Hobisch A, Hittmair A, Daxenbichler G, Wille S, Radmayr C, HobischHagen P, Bartsch G, Klocker H \& Culig Z 1997 Metastatic lesions from prostate cancer do not express oestrogen and progesterone receptors. Journal of Pathology 182 356-361. (https://doi.org/10.1002/ (SICI)1096-9896(199707)182:3<356::AID-PATH863>3.0.CO;2-U)

Huggins C \& Hodges C 1941 The effect of castration, of estrogen and of androgen injection on serum phosphatases in metastatic carcinoma of the prostate. Cancer Research 1 293-297.

Irelli A, Bruera G, Cannita K, Palluzzi E, Gravina GL, Festuccia C, Ficorella C \& Ricevuto E 2014 Bioclinical parameters driving decision-making of subsequent lines of treatment in metastatic castration-resistant prostate cancer. BioMed Research International 2014 909623. (https://doi.org/10.1155/2014/909623)

Jakobsson J, Ekström L, Inotsume N, Garle M, Lorentzon M, Ohlsson C, Roh H-K, Carlström K \& Rane A 2006 Large differences in testosterone excretion in Korean and Swedish men are strongly associated with a UDP-glucuronosyl transferase 2B17 polymorphism. Journal of Clinical Endocrinology and Metabolism 91 687-693. (https://doi.org/10.1210/jc.2005-1643)

Jarrossay D \& Thelen M 2013 Immune response: steroids drive dendritic cells. Nature Immunology 14 424-426. (https://doi.org/10.1038/ ni.2589)

Jernberg E, Thysell E, Bovinder Ylitalo E, Rudolfsson S, Crnalic S, Widmark A, Bergh A \& Wikstrom P 2013 Characterization of prostate cancer bone metastases according to expression levels of steroidogenic enzymes and androgen receptor splice variants. PLoS ONE 8 e77407. (https://doi.org/10.1371/journal.pone.0077407)

Joseph MA, Wei JT, Harlow SD, Cooney KA, Dunn RL, Jaffe CA, Montie JE \& Schottenfeld D 2002 Relationship of serum sex-steroid hormones and prostate volume in African American men. Prostate 53 322-329. (https://doi.org/10.1002/pros.10154)

Kanda S, Tsuchiya N, Narita S, Inoue T, Huang M, Chiba S, Akihama S, Saito M, Numakura K, Tsuruta H, et al. 2015 Effects of functional genetic polymorphisms in the CYP19A1 gene on prostate cancer risk and survival. International Journal of Cancer 136 74-82. (https://doi. org/10.1002/ijc.28952)

Kawakami J \& Morales A 2013 Clinical significance of suboptimal hormonal levels in men with prostate cancer treated with LHRH agonists. Canadian Urological Association Journal 7 E226-E230. (https://doi.org/10.5489/cuaj.540)

Kim W, Zhang L, Wilton JH, Fetterly G, Mohler JL, Weinberg V, Morse A, Szmulewitz RZ, Friedlander TW, Fong L, et al. 2014 Sequential use of the androgen synthesis inhibitors ketoconazole and abiraterone acetate in castration-resistant prostate cancer and the predictive value of circulating androgens. Clinical Cancer Research 20 6269-6276. (https://doi.org/10.1158/1078-0432.CCR-14-1595)

Kissick HT, Sanda MG, Dunn LK, Pellegrini KL, On ST, Noel JK \& Arredouani MS 2014 Androgens alter T-cell immunity by inhibiting T-helper 1 differentiation. PNAS 111 9887-9892. (https://doi. org/10.1073/pnas.1402468111)

Klap J, Schmid M \& Loughlin KR 2015 The relationship between total testosterone levels and prostate cancer: a review of the continuing controversy. Journal of Urology 193 403-413. (https://doi. org/10.1016/j.juro.2014.07.123)

Klotz L, O'Callaghan C, Ding K, Toren P, Dearnaley D, Higano CS, Horwitz E, Malone S, Goldenberg L, Gospodarowicz M, et al. 2015 Nadir testosterone within first year of androgen-deprivation therapy (ADT) predicts for time to castration-resistant progression: a secondary analysis of the PR-7 trial of intermittent versus continuous
ADT. Journal of Clinical Oncology 33 1151-1156. (https://doi. org/10.1200/JCO.2014.58.2973)

Klotz L, Breau RH, Collins LL, Gleave ME, Pickles T, Pouliot F \& Saad F 2017 Maximal testosterone suppression in the management of recurrent and metastatic prostate cancer. Canadian Urological Association Journal 11 16-23. (https://doi.org/10.5489/cuaj.4303)

Koh YT, Gray A, Higgins SA, Hubby B \& Kast WM 2009 Androgen ablation augments prostate cancer vaccine immunogenicity only when applied after immunization. Prostate 69 571-584. (https://doi. org/10.1002/pros.20906)

Komatsu S, Hara N, Ishizaki F, Nishiyama T, Takizawa I, Isahaya E, Kawasaki T \& Takahashi K 2012 Altered association of interleukin-6 with sex steroids in lipid metabolism disorder in men with prostate cancer receiving androgen deprivation therapy. Prostate $\mathbf{7 2}$ 1207-1213. (https://doi.org/10.1002/pros.22471)

Kovats S, Carreras E \& Agrawal H 2010 Sex steroid receptors in immune cells. In Sex Hormones and Immunity to Infection, pp 53-92. Eds S Klein \& C Roberts. Berlin, Germany: Springer-Verlag.

Kristal AR, Till C, Tangen CM, Goodman PJ, Neuhouser ML, Stanczyk FZ, Chu LW, Patel SK, Thompson IM, Reichardt JK, et al. 2012 Associations of serum sex steroid hormone and $5 \alpha$-androstane$3 \alpha, 17 \beta$-diol glucuronide concentrations with prostate cancer risk among men treated with finasteride. Cancer Epidemiology, Biomarkers and Prevention 21 1823-1832. (https://doi.org/10.1158/1055-9965. EPI-12-0695)

Kumazawa T, Tsuchiya N, Wang L, Sato K, Kamoto T, Ogawa O, Nakamura A, Kato T \& Habuchi T 2004 Microsatellite polymorphism of steroid hormone synthesis gene CYP11A1 is associated with advanced prostate cancer. International Journal of Cancer $\mathbf{1 1 0}$ 140-144. (https://doi.org/10.1002/ijc.20070)

Latil A, Bièche I, Vidaud D, Lidereau R, Berthon P, Cussenot O \& Vidaud M 2001 Evaluation of androgen, estrogen (ER alpha and ER beta), and progesterone receptor expression in human prostate cancer by real-time quantitative reverse transcription-polymerase chain reaction assays. Cancer Research 61 1919-1926.

Lau K-M \& To K-F 2016 Importance of estrogenic signaling and its mediated receptors in prostate cancer. International Journal of Molecular Sciences 17 E1434. (https://doi.org/10.3390/ijms17091434)

Lélu K, Laffont S, Delpy L, Paulet P-E, Périnat T, Tschanz SA, Pelletier L, Engelhardt B \& Guéry J-C 2011 Estrogen receptor $\alpha$ signaling in T lymphocytes is required for estradiol-mediated inhibition of Th1 and Th17 cell differentiation and protection against experimental autoimmune encephalomyelitis. Journal of Immunology 187 2386-2393. (https://doi.org/10.4049/jimmunol.1101578)

Levesque E, Huang SP, Audet-Walsh E, Lacombe L, Bao BY, Fradet Y, Laverdiere I, Rouleau M, Huang CY, Yu CC, et al. 2013 Molecular markers in key steroidogenic pathways, circulating steroid levels, and prostate cancer progression. Clinical Cancer Research 19 699-709. (https://doi.org/10.1158/1078-0432.CCR-12-2812)

Lévesque E, Laverdière I, Audet-Walsh E, Caron P, Rouleau M, Fradet Y, Lacombe L \& Guillemette C 2014 Steroidogenic germline polymorphism predictors of prostate cancer progression in the estradiol pathway. Clinical Cancer Research 20 2971-2983. (https://doi.org/10.1158/1078-0432.CCR-13-2567)

Lin P-Y, Sun L, Thibodeaux SR, Ludwig SM, Vadlamudi RK, Hurez VJ, Bahar R, Kious MJ, Livi CB, Wall SR, et al. 2010 B7-H1-dependent sex-related differences in tumor immunity and immunotherapy responses. Journal of Immunology 185 2747-2753. (https://doi. org/10.4049/jimmunol.1000496)

Litman HJ, Bhasin S, Link CL, Araujo AB \& McKinlay JB 2006 Serum androgen levels in black, hispanic, and white men. Journal of Clinical Endocrinology and Metabolism 91 4326-4334. (https://doi. org/10.1210/jc.2006-0037)

Liu C, Lou W, Zhu Y, Yang JC, Nadiminty N, Gaikwad NW, Evans CP \& Gao AC 2015 Intracrine androgens and AKR1C3 activation confer
(C) 2018 Society for Endocrinology Published by Bioscientifica Ltd. Printed in Great Britain 
resistance to enzalutamide in prostate cancer. Cancer Research $\mathbf{7 5}$ 1413-1422. (https://doi.org/10.1158/0008-5472.CAN-14-3080)

Liva SM \& Voskuhl RR 2001 Testosterone acts directly on CD4+ T lymphocytes to increase IL-10 production. Journal of Immunology $\mathbf{1 6 7}$ 2060-2067. (https://doi.org/10.4049/jimmunol.167.4.2060)

Llukani E, Katz BF, Agalliu I, Lightfoot A, Yu S-JS, Kathrins M, Lee Z, Su Y-K, Monahan Agnew K, McGill A, et al. 2017 Low levels of serum testosterone in middle-aged men impact pathological features of prostate cancer. Prostate International 5 17-23. (https://doi. org/10.1016/j.prnil.2016.12.003)

Locke JA, Fazli L, Adomat H, Smyl J, Weins K, Lubik AA, Hales DB, Nelson CC, Gleave ME \& Tomlinson Guns ES 2009 A novel communication role for CYP17A1 in the progression of castrationresistant prostate cancer. Prostate 69 928-937. (https://doi. org/10.1002/pros.20940)

Lu X, Horner JW, Paul E, Shang X, Troncoso P, Deng P, Jiang S, Chang Q, Spring DJ, Sharma P, et al. 2017 Effective combinatorial immunotherapy for castration-resistant prostate cancer. Nature $\mathbf{5 4 3}$ 728-732. (https://doi.org/10.1038/nature21676)

Lukka H, Waldron T, Klotz L, Winquist E, Trachtenberg J, Genitourinary Cancer Disease Site Group \& Cancer Care Ontario Program in Evidence-based Care 2006 Maximal androgen blockade for the treatment of metastatic prostate cancer - a systematic review. Current Oncology 13 81-93.

Maret A, Coudert JD, Garidou L, Foucras G, Gourdy P, Krust A, Dupont S, Chambon P, Druet P, Bayard F, et al. 2003 Estradiol enhances primary antigen-specific CD4 T cell responses and Th1 development in vivo. Essential role of estrogen receptor alpha expression in hematopoietic cells. European Journal of Immunology $\mathbf{3} 3$ 512-521. (https://doi.org/10.1002/immu.200310027)

Margel D \& Fleshner NE 2011 Oral contraceptive use is associated with prostate cancer: an ecological study. BMJ Open 1 e000311. (https://doi.org/10.1136/bmjopen-2011-000311)

Marks LS, Hess DL, Dorey FJ, Luz Macairan M, Cruz Santos PB \& Tyler VE 2001 Tissue effects of saw palmetto and finasteride: use of biopsy cores for in situ quantification of prostatic androgens. Urology 57 999-1005. (https://doi.org/10.1016/S0090-4295(00)01052-9)

McKay RR, Werner L, Mostaghel EA, Lis R, Voznesensky O, Zhang Z, Marck BT, Matsumoto AM, Domachevsky L, Zukotynski KA, et al. 2017 A phase II trial of abiraterone combined with dutasteride for men with metastatic castration-resistant prostate cancer. Clinical Cancer Research 23 935-945. (https://doi.org/10.1158/1078-0432. CCR-16-0987)

Meier A, Chang JJ, Chan ES, Pollard RB, Sidhu HK, Kulkarni S, Wen TF, Lindsay RJ, Orellana L, Mildvan D, et al. 2009 Sex differences in the Toll-like receptor-mediated response of plasmacytoid dendritic cells to HIV-1. Nature Medicine 15 955-959. (https://doi.org/10.1038/ nm.2004)

Mitsiades N, Sung CC, Schultz N, Danila DC, He B, Eedunuri VK, Fleisher M, Sander C, Sawyers CL \& Scher HI 2012 Distinct patterns of dysregulated expression of enzymes involved in androgen synthesis and metabolism in metastatic prostate cancer tumors. Cancer Research 72 6142-6152. (https://doi.org/10.1158/0008-5472. can-12-1335)

Miyazawa Y, Sekine Y, Syuto T, Nomura M, Koike H, Matsui H, Shibata Y, Ito K \& Suzuki K 2017 A gonadotropin-releasing hormone antagonist reduces serum adrenal androgen levels in prostate cancer patients. BMC Urology 17 70. (https://doi.org/10.1186/s12894-0170261-z)

Miyoshi Y, Uemura H, Umemoto S, Sakamaki K, Morita S, Suzuki K, Shibata Y, Masumori N, Ichikawa T, Mizokami A, et al. 2014 High testosterone levels in prostate tissue obtained by needle biopsy correlate with poor-prognosis factors in prostate cancer patients. BMC Cancer 14 717. (https://doi.org/10.1186/1471-2407-14-717)

Miyoshi Y, Uemura H, Umemoto S, Sakamaki K, Taguri M, Suzuki K, Shibata Y, Masumori N, Ichikawa T, Mizokami A, et al. 2016
Low serum dehydroepiandrosterone examined by liquid chromatography-tandem mass spectrometry correlates with poor prognosis in hormone-naïve prostate cancer. Prostate 76 376-382. (https://doi.org/10.1002/pros.23129)

Mizokami A, Koh E, Fujita H, Maeda Y, Egawa M, Koshida K, Honma S, Keller ET \& Namiki M 2004 The adrenal androgen androstenediol is present in prostate cancer tissue after androgen deprivation therapy and activates mutated androgen receptor. Cancer Research 64 765-771. (https://doi.org/10.1158/0008-5472.CAN-03-0130)

Montgomery RB, Mostaghel EA, Vessella R, Hess DL, Kalhorn TF, Higano CS, True LD \& Nelson PS 2008 Maintenance of intratumoral androgens in metastatic prostate cancer: a mechanism for castrationresistant tumor growth. Cancer Research 68 4447-4454. (https://doi. org/10.1158/0008-5472.CAN-08-0249)

Morote J, Orsola A, Planas J, Trilla E, Raventos CX, Cecchini L \& Catalan R 2007 Redefining clinically significant castration levels in patients with prostate cancer receiving continuous androgen deprivation therapy. Journal of Urology 178 1290-1295. (https://doi. org/10.1016/j.juro.2007.05.129)

Morse MD \& McNeel DG 2012 T cells localized to the androgendeprived prostate are TH1 and TH17 biased. Prostate 72 1239-1247. (https://doi.org/10.1002/pros.22476)

Mostaghel EA, Page ST, Lin DW, Fazli L, Coleman IM, True LD, Knudsen B, Hess DL, Nelson CC, Matsumoto AM, et al. 2007 Intraprostatic androgens and androgen-regulated gene expression persist after testosterone suppression: therapeutic implications for castration-resistant prostate cancer. Cancer Research 67 5033-5041. (https://doi.org/10.1158/0008-5472.CAN-06-3332)

Mostaghel EA, Lin DW, Amory JK, Wright JL, Marck BT, Nelson PS, Matsumoto AM, Bremner WJ \& Page ST 2012 Impact of male hormonal contraception on prostate androgens and androgen action in healthy men: a randomized, controlled trial. Journal of Clinical Endocrinology and Metabolism 97 2809-2817. (https://doi. org/10.1210/jc.2012-1536)

Mostaghel EA, Nelson PS, Lange P, Lin DW, Taplin ME, Balk S, Ellis W, Kantoff P, Marck B, Tamae D, et al. 2014 Targeted androgen pathway suppression in localized prostate cancer: a pilot study. Journal of Clinical Oncology 32 229-237. (https://doi.org/10.1200/ JCO.2012.48.6431)

Muller RL, Gerber L, Moreira DM, Andriole G, Castro-Santamaria R \& Freedland SJ 2012 Serum testosterone and dihydrotestosterone and prostate cancer risk in the placebo arm of the Reduction by Dutasteride of Prostate Cancer Events trial. European Urology 62 757-764. (https://doi.org/10.1016/j.eururo.2012.05.025)

Musabak U, Bolu E, Ozata M, Oktenli C, Sengul A, Inal A, Yesilova Z, Kilciler G, Ozdemir IC \& Kocar IH 2003 Gonadotropin treatment restores in vitro interleukin-1beta and tumour necrosis factor-alpha production by stimulated peripheral blood mononuclear cells from patients with idiopathic hypogonadotropic hypogonadism. Clinical and Experimental Immunology 132 265-270. (https://doi. org/10.1046/j.1365-2249.2003.02141.x

Nadeau G, Bellemare J, Audet-Walsh É, Flageole C, Huang S-P, Bao B-Y, Douville P, Caron P, Fradet Y, Lacombe L, et al. 2011 Deletions of the androgen-metabolizing UGT2B genes have an effect on circulating steroid levels and biochemical recurrence after radical prostatectomy in localized prostate cancer. Journal of Clinical Endocrinology and Metabolism 96 E1550-E1557. (https://doi.org/10.1210/jc.2011-1049)

Neuzillet Y, Raynaud J-P, Radulescu C, Fiet J, Giton F, Dreyfus J-F, Ghoneim TP, Lebret T \& Botto H 2017 Sexual steroids in serum and prostatic tissue of human non-cancerous prostate (STERPROSER trial). Prostate 77 1512-1519. (https://doi.org/10.1002/pros.23429)

Newton MR, Phillips S, Chang SS, Clark PE, Cookson MS, Davis R, Fowke JH, Herrell SD, Baumgartner R, Chan R, et al. 2010 Smaller prostate size predicts high grade prostate cancer at final pathology. Journal of Urology 184 930-937. (https://doi.org/10.1016/j. juro.2010.04.082)
(C) 2018 Society for Endocrinology Published by Bioscientifica Ltd. Printed in Great Britain 
Nishii M, Nomura M, Sekine Y, Koike H, Matsui H, Shibata Y, Ito K, Oyama T \& Suzuki K 2012 Luteinizing hormone (LH)-releasing hormone agonist reduces serum adrenal androgen levels in prostate cancer patients: implications for the effect of LH on the adrenal glands. Journal of Andrology 33 1233-1238. (https://doi.org/10.2164/ jandrol.112.016493)

Nishiyama T, Ikarashi T, Hashimoto Y, Wako K \& Takahashi K 2007 The change in the dihydrotestosterone level in the prostate before and after androgen deprivation therapy in connection with prostate cancer aggressiveness using the Gleason score. Journal of Urology $\mathbf{1 7 8}$ 1288-1289. (https://doi.org/10.1016/j.juro.2007.05.138)

Niu Y, Ge R, Hu L, Diaz C, Wang Z, Wu C-L \& Olumi AF 2011 Reduced levels of $5-\alpha$ reductase 2 in adult prostate tissue and implications for BPH therapy. Prostate 71 1317-1324. (https://doi.org/10.1002/ pros.21348)

Noble RL 1977 The development of prostatic adenocarcinoma in $\mathrm{Nb}$ rats following prolonged sex hormone administration. Cancer Research $\mathbf{3 7}$ 1929-1933.

Oka H, Negoro H, Sugino Y, Iwamura H, Moroi S \& Kawakita M 2003 Change of serum adrenal androgens in prostatic cancer patients after bilateral orchidectomy or LHRH agonist treatment. Hinyokika Kiyo. Acta Urologica Japonica 49 521-525.

Olsen NJ \& Kovacs WJ 1996 Gonadal steroids and immunity. Endocrine Reviews 17 369-384. (https://doi.org/10.1210/edrv-17-4-369)

Olsson M, Ekström L, Schulze J, Kjellman A, Akre O, Rane A \& Gustafsson O 2010 Radical prostatectomy: influence on serum and urinary androgen levels. Prostate 70 200-205. (https://doi. org/10.1002/pros.21053)

Olsson M, Ekström L, Guillemette C, Belanger A, Rane A \& Gustafsson O 2011 Correlation between circulatory, local prostatic, and intraprostatic androgen levels. Prostate 71 909-914. (https://doi. org/10.1002/pros.21307)

Page ST, Plymate SR, Bremner WJ, Matsumoto AM, Hess DL, Lin DW, Amory JK, Nelson PS \& Wu JD 2006 Effect of medical castration on CD4+ CD25+ T cells, CD8+ T cell IFN-gamma expression, and NK cells: a physiological role for testosterone and/or its metabolites. American Journal of Physiology: Endocrinology and Metabolism 290 E856-E863. (https://doi.org/10.1152/ajpendo.00484.2005)

Page ST, Lin DW, Mostaghel EA, Marck BT, Wright JL, Wu J, Amory JK, Nelson PS \& Matsumoto AM 2011 Dihydrotestosterone administration does not increase intraprostatic androgen concentrations or alter prostate androgen action in healthy men: a randomized-controlled trial. Journal of Clinical Endocrinology and Metabolism 96 430-437. (https://doi.org/10.1210/jc.2010-1865)

Park J, Cho SY, Jeong S-H, Lee SB, Son H \& Jeong H 2016 Low testosterone level is an independent risk factor for high-grade prostate cancer detection at biopsy. BJU International 118 230-235. (https://doi.org/10.1111/bju.13206)

Perachino M, Cavalli V \& Bravi F 2010 Testosterone levels in patients with metastatic prostate cancer treated with luteinizing hormonereleasing hormone therapy: prognostic significance? BJU International 105 648-651. (https://doi.org/10.1111/j.1464-410X.2009.08814.x)

Piao Y, Wiesenfeld P, Sprando R \& Arnold JT 2013 TGF $\beta 1$ alters androgenic metabolites and hydroxysteroid dehydrogenase enzyme expression in human prostate reactive stromal primary cells: is steroid metabolism altered by prostate reactive stromal microenvironment? Journal of Steroid Biochemistry and Molecular Biology 138 206-213. (https://doi.org/10.1016/j.jsbmb.2013.05.016)

Pickles T, Hamm J, Morris WJ, Schreiber WE \& Tyldesley S 2012 Incomplete testosterone suppression with luteinizing hormonereleasing hormone agonists: does it happen and does it matter? BJU International 110 E500-E507. (https://doi. org/10.1111/j.1464-410X.2012.11190.x)

Pioli PA, Jensen AL, Weaver LK, Amiel E, Shen Z, Shen L, Wira CR \& Guyre PM 2007 Estradiol attenuates lipopolysaccharide-induced CXC chemokine ligand 8 production by human peripheral blood monocytes. Journal of Immunology 179 6284-6290. (https://doi. org/10.4049/jimmunol.179.9.6284)

Polanczyk MJ, Carson BD, Subramanian S, Afentoulis M, Vandenbark AA, Ziegler SF \& Offner H 2004 Cutting edge: estrogen drives expansion of the CD4+CD25+ regulatory T cell compartment. Journal of Immunology 173 2227-2230. (https://doi.org/10.4049/ jimmunol.173.4.2227)

Polanczyk MJ, Hopke C, Vandenbark AA \& Offner H 2007 Treg suppressive activity involves estrogen-dependent expression of programmed death-1 (PD-1). International Immunology 19 337-343. (https://doi.org/10.1093/intimm/dxl151)

Ren X, Fu X, Zhang X, Chen S, Huang S, Yao L \& Liu G 2017 Testosterone regulates 3T3-L1 pre-adipocyte differentiation and epididymal fat accumulation in mice through modulating macrophage polarization. Biochemical Pharmacology 140 73-88. (https://doi.org/10.1016/j.bcp.2017.05.022)

Rettew JA, Huet-Hudson YM \& Marriott I 2008 Testosterone reduces macrophage expression in the mouse of toll-like receptor 4 , a trigger for inflammation and innate immunity. Biology of Reproduction $\mathbf{7 8}$ 432-437. (https://doi.org/10.1095/biolreprod.107.063545)

Ricke WA, McPherson SJ, Bianco JJ, Cunha GR, Wang Y \& Risbridger GP 2008 Prostatic hormonal carcinogenesis is mediated by in situ estrogen production and estrogen receptor alpha signaling. FASEB Journal 22 1512-1520. (https://doi.org/10.1096/fj.07-9526com)

Roden AC, Moser MT, Tri SD, Mercader M, Kuntz SM, Dong H, Hurwitz AA, McKean DJ, Celis E, Leibovich BC, et al. 2004 Augmentation of $\mathrm{T}$ cell levels and responses induced by androgen deprivation. Journal of Immunology 173 6098-6108. (https://doi. org/10.4049/jimmunol.173.10.6098)

Rohrmann S, Nelson WG, Rifai N, Brown TR, Dobs A, Kanarek N, Yager JD \& Platz EA 2007 Serum estrogen, but not testosterone, levels differ between black and white men in a nationally representative sample of Americans. Journal of Clinical Endocrinology and Metabolism 92 2519-2525. (https://doi.org/10.1210/jc.20070028)

Roved J, Westerdahl H \& Hasselquist D 2017 Sex differences in immune responses: Hormonal effects, antagonistic selection, and evolutionary consequences. Hormones and Behavior 88 95-105. (https://doi. org/10.1016/j.yhbeh.2016.11.017)

Ryan CJ, Smith MR, de Bono JS, Molina A, Logothetis CJ, de Souza P, Fizazi K, Mainwaring P, Piulats JM, Ng S, et al. 2013a Abiraterone in metastatic prostate cancer without previous chemotherapy. New England Journal of Medicine 368 138-148. (https://doi.org/10.1056/ NEJMoa1209096)

Ryan CJ, Molina A, Li J, Kheoh T, Small EJ, Haqq CM, Grant RP, de Bono JS \& Scher HI 2013b Serum androgens as prognostic biomarkers in castration-resistant prostate cancer: results from an analysis of a randomized phase III trial. Journal of Clinical Oncology 31 2791-2798. (https://doi.org/10.1200/JCO.2012.45.4595)

Ryan CJ, Peng W, Kheoh T, Welkowsky E, Haqq CM, Chandler DW, Scher HI \& Molina A 2014 Androgen dynamics and serum PSA in patients treated with abiraterone acetate. Prostate Cancer and Prostatic Diseases 17 192-198. (https://doi.org/10.1038/pcan.2014.8)

Santen RJ, Petroni GR, Fisch MJ, Myers CE, Theodorescu D \& Cohen RB 2001 Use of the aromatase inhibitor anastrozole in the treatment of patients with advanced prostate carcinoma. Cancer 92 2095-2101. (https://doi.org/10.1002/1097-0142(20011015)92:8<2095::AIDCNCR1550>3.0.CO;2-Y)

Sayyid RK, Evans A, Hersey K, Maloni R, Hurtado-Coll A, Kulkarni G, Finelli A, Zlotta AR, Hamilton R, Gleave M, et al. 2017 A phase II, randomized, open-label study of neoadjuvant degarelix versus LHRH agonist in prostate cancer patients prior to radical prostatectomy. Clinical Cancer Research 23 1974-1980. (https://doi. org/10.1158/1078-0432.CCR-16-1790)

Schatzl G, Reiter WJ, Thürridl T, Waldmüller J, Roden M, Söregi S \& Madersbacher S 2000 Endocrine patterns in patients with benign 
and malignant prostatic diseases. Prostate 44 219-224. (https://doi. org/10.1002/1097-0045(20000801)44:3<219::AID-PROS6>3.0.CO;2-I)

Severi G, Morris HA, MacInnis RJ, English DR, Tilley W, Hopper JL, Boyle P \& Giles GG 2006 Circulating steroid hormones and the risk of prostate cancer. Cancer Epidemiology, Biomarkers and Prevention 15 86-91. (https://doi.org/10.1158/1055-9965.EPI-05-0633)

Sharifi N, Hamada A, Sissung T, Danesi R, Venzon D, Baum C, Gulley JL, Price DK, Dahut WL \& Figg WD 2008 A polymorphism in a transporter of testosterone is a determinant of androgen independence in prostate cancer. BJU International 102 617-621. (https://doi.org/10.1111/j.1464-410X.2008.07629.x)

Sher DJ, Mantzoros C, Jacobus S, Regan MM, Lee G-S \& Oh WK 2009 Absence of relationship between steroid hormone levels and prostate cancer tumor grade. Urology 73 356-361. (https://doi.org/10.1016/j. urology.2008.07.068)

Shibata Y, Suzuki K, Arai S, Miyoshi Y, Umemoto S, Masumori N, Kamiya N, Ichikawa T, Kitagawa Y, Mizokami A, et al. 2013 Impact of pre-treatment prostate tissue androgen content on the prediction of castration-resistant prostate cancer development in patients treated with primary androgen deprivation therapy. Andrology $\mathbf{1}$ 505-511. (https://doi.org/10.1111/j.2047-2927.2013.00068.x)

Shiota M, Fujimoto N, Yokomizo A, Takeuchi A, Itsumi M, Inokuchi J, Tatsugami K, Uchiumi T \& Naito S 2015 SRD5A gene polymorphism in Japanese men predicts prognosis of metastatic prostate cancer with androgen-deprivation therapy. European Journal of Cancer $\mathbf{5 1}$ 1962-1969. (https://doi.org/10.1016/j.ejca.2015.06.122)

Shiota M, Fujimoto N, Yokomizo A, Takeuchi A, Kashiwagi E, Dejima T, Kiyoshima K, Inokuchi J, Tatsugami K \& Eto M 2016 The prognostic impact of serum testosterone during androgen-deprivation therapy in patients with metastatic prostate cancer and the SRD5A2 polymorphism. Prostate Cancer and Prostatic Diseases 19 191-196. (https://doi.org/10.1038/pcan.2016.2)

van der Sluis TM, Vis AN, van Moorselaar RJA, Bui HN, Blankenstein MA, Meuleman EJH \& Heijboer AC 2012 Intraprostatic testosterone and dihydrotestosterone. Part I: concentrations and methods of determination in men with benign prostatic hyperplasia and prostate cancer. BJU International 109 176-182. (https://doi. org/10.1111/j.1464-410X.2011.10651.x)

Smith MR, Kaufman D, George D, Oh WK, Kazanis M, Manola J \& Kantoff PW 2002 Selective aromatase inhibition for patients with androgen-independent prostate carcinoma. Cancer 95 1864-1868. (https://doi.org/10.1002/cncr.10844)

Spitzer JA 1999 Gender differences in some host defense mechanisms. Lupus 8 380-383. (https://doi.org/10.1177/096120339900800510)

Stanbrough M, Bubley GJ, Ross K, Golub TR, Rubin MA, Penning TM, Febbo PG \& Balk SP 2006 Increased expression of genes converting adrenal androgens to testosterone in androgen-independent prostate cancer. Cancer Research 66 2815-2825. (https://doi.org/10.1158/00085472.CAN-05-4000)

Strömvall K, Sundkvist K, Ljungberg B, Halin Bergström S \& Bergh A 2017 Reduced number of CD169(+) macrophages in pre-metastatic regional lymph nodes is associated with subsequent metastatic disease in an animal model and with poor outcome in prostate cancer patients. Prostate 77 1468-1477. (https://doi.org/10.1002/ pros.23407)

Sun T, Oh WK, Jacobus S, Regan M, Pomerantz M, Freedman ML, Lee G-SM \& Kantoff PW 2011 The impact of common genetic variations in genes of the sex hormone metabolic pathways on steroid hormone levels and prostate cancer aggressiveness. Cancer Prevention Research 4 2044-2050. (https://doi.org/10.1158/19406207.CAPR-11-0283)

Sutherland JS, Goldberg GL, Hammett MV, Uldrich AP, Berzins SP, Heng TS, Blazar BR, Millar JL, Malin MA, Chidgey AP, et al. 2005 Activation of thymic regeneration in mice and humans following androgen blockade. Journal of Immunology 175 2741-2753. (https://doi.org/10.4049/jimmunol.175.4.2741)
Svoronos N, Perales-Puchalt A, Allegrezza MJ, Rutkowski MR, Payne KK, Tesone AJ, Nguyen JM, Curiel TJ, Cadungog MG, Singhal S, et al. 2017 Tumor cell-independent estrogen signaling drives disease progression through mobilization of myeloid-derived suppressor cells. Cancer Discovery 7 72-85. (https://doi.org/10.1158/2159-8290. CD-16-0502)

Takase Y, Levesque MH, Luu-The V, El-Alfy M, Labrie F \& Pelletier G 2006 Expression of enzymes involved in estrogen metabolism in human prostate. Journal of Histochemistry and Cytochemistry $\mathbf{5 4}$ 911-921. (https://doi.org/10.1369/jhc.6A6927.2006)

Takizawa I, Nishiyama T, Hara N, Isahaya E, Hoshii T \& Takahashi K 2010 Serum prostate-specific antigen levels reflect the androgen milieu in patients with localized prostate cancer receiving androgen deprivation therapy: tumor malignant potential and androgen milieu. Prostate 70 1395-1401. (https://doi.org/10.1002/pros.21174)

Thirumalai A, Cooper LA, Rubinow KB, Amory JK, Lin DW, Wright JL, Marck BT, Matsumoto AM \& Page ST 2016 Stable intraprostatic dihydrotestosterone in healthy medically castrate men treated with exogenous testosterone. Journal of Clinical Endocrinology and Metabolism 101 2937-2944. (https://doi.org/10.1210/jc.2016-1483)

Thompson IM, Goodman PJ, Tangen CM, Lucia MS, Miller GJ, Ford LG, Lieber MM, Cespedes RD, Atkins JN, Lippman SM, et al. 2003 The influence of finasteride on the development of prostate cancer. New England Journal of Medicine 349 215-224. (https://doi.org/10.1056/ NEJMoa030660)

Titus MA, Schell MJ, Lih FB, Tomer KB \& Mohler JL 2005 Testosterone and dihydrotestosterone tissue levels in recurrent prostate cancer. Clinical Cancer Research 11 4653-4657. (https://doi org/10.1158/1078-0432.CCR-05-0525)

Tombal B, Cornel EB, Persad R, Stari A, Veiga FG \& Schulman C 2017 Clinical outcomes and testosterone levels following continuous androgen deprivation in patients with relapsing or locally advanced prostate cancer: a post hoc analysis of the ICELAND study. Journal of Urology 198 1054-1060. (https://doi.org/10.1016/j.juro.2017.05.072)

Toren P \& Venkateswaran V 2014 Periprostatic adipose tissue and prostate cancer progression: new insights into the tumor microenvironment. Clinical Genitourinary Cancer 12 21-26. (https://doi.org/10.1016/j.clgc.2013.07.013)

Travis RC, Schumacher F, Hirschhorn JN, Kraft P, Allen NE, Albanes D, Berglund G, Berndt SI, Boeing H, Bueno-de-Mesquita HB, et al. 2009 CYP19A1 genetic variation in relation to prostate cancer risk and circulating sex hormone concentrations in men from the Breast and Prostate Cancer Cohort Consortium. Cancer Epidemiology, Biomarkers and Prevention 18 2734-2744. (https://doi.org/10.1158/1055-9965. EPI-09-0496)

Trigunaite A, Dimo J \& Jørgensen TN 2015 Suppressive effects of androgens on the immune system. Cellular Immunology 294 87-94. (https://doi.org/10.1016/j.cellimm.2015.02.004)

Vermeulen A, Kaufman JM, Goemaere S \& van Pottelberg I 2002 Estradiol in elderly men. Aging Male 5 98-102. (https://doi. org/10.1080/tam.5.2.98.102)

Vuk-Pavlović S, Bulur PA, Lin Y, Qin R, Szumlanski CL, Zhao X \& Dietz AB 2010 Immunosuppressive CD14+HLA-DRlow/- monocytes in prostate cancer. Prostate 70 443-455. (https://doi.org/10.1002/ pros.21078)

Walton TJ, Li G, McCulloch TA, Seth R, Powe DG, Bishop MC \& Rees RC 2009 Quantitative RT-PCR analysis of estrogen receptor gene expression in laser microdissected prostate cancer tissue. Prostate 69 810-819. (https://doi.org/10.1002/pros.20929)

Wang X, Harshman LC, Xie W, Nakabayashi M, Qu F, Pomerantz MM, Lee GS \& Kantoff PW 2016 Association of SLCO2B1 genotypes with time to progression and overall survival in patients receiving androgen-deprivation therapy for prostate cancer. Journal of Clinical Oncology 34 352-359. (https://doi.org/10.1200/JCO.2015.62.5988)

Wang Y, Dai B \& Ye D-W 2017a Serum testosterone level predicts the effective time of androgen deprivation therapy in metastatic prostate (c) 2018 Society for Endocrinology Published by Bioscientifica Ltd. Printed in Great Britain 
cancer patients. Asian Journal of Andrology 19 178-183. (https://doi. org/10.4103/1008-682X.174856)

Wang X, Yang L, Huang F, Zhang Q, Liu S, Ma L \& You Z 2017b Inflammatory cytokines IL-17 and TNF- $\alpha$ up-regulate PD-L1 expression in human prostate and colon cancer cells. Immunology Letters 184 7-14. (https://doi.org/10.1016/j.imlet.2017.02.006)

Weiss JM, Huang W-Y, Rinaldi S, Fears TR, Chatterjee N, Hsing AW, Crawford ED, Andriole GL, Kaaks R \& Hayes RB 2008 Endogenous sex hormones and the risk of prostate cancer: a prospective study. International Journal of Cancer 122 2345-2350. (https://doi. org/10.1002/ijc.23326)

Wright JL, Kwon EM, Ostrander EA, Montgomery RB, Lin DW, Vessella R, Stanford JL \& Mostaghel EA 2011 Expression of SLCO transport genes in castration-resistant prostate cancer and impact of genetic variation in SLCO1B3 and SLCO2B1 on prostate cancer outcomes. Cancer Epidemiology, Biomarkers and Prevention 20 619-627. (https://doi.org/10.1158/1055-9965.EPI-10-1023)

Wu G, Huang S, Nastiuk KL, Li J, Gu J, Wu M, Zhang Q, Lin H \& Wu D 2015 Variant allele of HSD3B1 increases progression to castrationresistant prostate cancer. Prostate 75 777-782. (https://doi. org/10.1002/pros.22967)

Xu T, Wang X, Hou S, Zhu J, Zhang X \& Huang X 2002 Effect of surgical castration on risk factors for arteriosclerosis of patients with prostate cancer. Chinese Medical Journal 115 1336-1340.

Xu X, Zhang X, Zhong Y, Saad F, Perez-Patron MJ, Haider K \& Haider A 2017 Dynamic patterns of testosterone levels within individuals and risk of prostate cancer among hypogonadal men: a longitudinal study. Journal of Urology 199 465-473. (https://doi.org/10.1016/j. juro.2017.08.117)

Yang M, Xie W, Mostaghel E, Nakabayashi M, Werner L, Sun T, Pomerantz M, Freedman M, Ross R, Regan M, et al. 2011 SLCO2B1 and SLCO1B3 may determine time to progression for patients receiving androgen deprivation therapy for prostate cancer. Journal of Clinical Oncology 29 2565-2573. (https://doi.org/10.1200/

JCO.2010.31.2405)

Yeap BB, Knuiman MW, Divitini ML, Handelsman DJ, Beilby JP, Beilin J, McQuillan B \& Hung J 2014 Differential associations of testosterone, dihydrotestosterone and oestradiol with physical, metabolic and health-related factors in community-dwelling men aged 17-97 years from the Busselton Health Survey. Clinical Endocrinology 81 100-108. (https://doi.org/10.1111/cen.12407)

Ylitalo EB, Thysell E, Jernberg E, Lundholm M, Crnalic S, Egevad L, Stattin P, Widmark A, Bergh A \& Wikstrom P 2016 Subgroups of castration-resistant prostate cancer bone metastases defined through an inverse relationship between androgen receptor activity and immune response. European Urology 71 776-787. (https://doi. org/10.1016/j.eururo.2016.07.033)

Yu Y, Liu L, Xie N, Xue H, Fazli L, Buttyan R, Wang Y, Gleave M \& Dong X 2013 Expression and function of the progesterone receptor in human prostate stroma provide novel insights to cell proliferation control. Journal of Clinical Endocrinology and Metabolism 98 2887-2896. (https://doi.org/10.1210/jc.2012-4000)

Zang T, Taplin M-E, Tamae D, Xie W, Mesaros C, Zhang Z, Bubley G, Montgomery B, Balk SP, Mostaghel EA, et al. 2017 Testicular vs adrenal sources of hydroxy-androgens in prostate cancer. EndocrineRelated Cancer 24 393-404. (https://doi.org/10.1530/ERC-17-0107)

Zhang Q, Hu Y, Cao J, Zhong Y, Zhao Y \& Mei Q 2004 Estrogen influences the differentiation, maturation and function of dendritic cells in rats with experimental autoimmune encephalomyelitis. Acta Pharmacologica Sinica 25 508-513.

Zhang A, Zhang J, Plymate S \& Mostaghel EA 2016 Classical and nonclassical roles for pre-receptor control of DHT metabolism in prostate cancer progression. Hormones and Cancer 7 104-113. (https://doi. org/10.1007/s12672-016-0250-9)

Received in final form 20 December 2017

Accepted 8 January 2018

Accepted Preprint published online 9 January 2018 http://erc.endocrinology-journals.org https://doi.org/10.1530/ERC-17-0493 (c) 2018 Society for Endocrinology Published by Bioscientifica Ltd. Printed in Great Britain 